\title{
Los canónigos doctorales en Portugal: orígenes sociales y carreras de una élite eclesiástica (siglos XVI y XVII) ${ }^{1}$
}

\author{
Ana Isabel López-Salazar ${ }^{2}$
}

Recibido: 30 de agosto de 2021 / Aceptado: 13 de octubre de 2021

Resumen: El objetivo del presente artículo es el estudio de las procedencias geográficas, las carreras en la Universidad, la Iglesia y la Administración y los orígenes sociales de los canónigos doctorales portugueses de los siglos XVI y XVII. Se trató de un grupo muy específico dentro de la Iglesia portuguesa, ya que las doctorales de las diócesis antiguas eran canonjías de patronato regio provistas por concurso en la Universidad de Coimbra. El análisis de los orígenes sociales de estos prebendados demuestra que las doctorales quedaron mayoritariamente en manos de la aristocracia no titulada, las élites locales, tanto de las ciudades como de las zonas rurales, y los grupos letrados vinculados al servicio regio.

Palabras clave: Portugal; clero; cabildos catedralicios; Historia Social.

\section{[en] Doctoral canons in Portugal: social origins and careers of an ecclesiastical elite $\left(16^{\text {th }}\right.$ and $17^{\text {th }}$ centuries $)$}

\begin{abstract}
The aim of this paper is the study of the geographical origins, the careers in University, Church and Administration, and the social background of the Portuguese doctoral canons in $16^{\text {th }}$ and $17^{\text {th }}$ centuries. It was a very specific group within the Portuguese Church, since the King was the royal patron of the doctoral canonries, and these benefices were granted after a public examination at the University of Coimbra. The analysis of the social origins of these canons shows that the doctoral canonries were mostly in the hands of untitled aristocracy (fidalguia), local elites -both in cities and rural areas-, and groups linked to the royal service in the Administration.
\end{abstract}

Keywords: Portugal; clergy; cathedral chapters; Social History.

Sumario: Introducción. Un apunte metodológico. Fuentes. Carreras eclesiásticas y políticas. Orígenes geográficos. Orígenes sociales. La alta nobleza: de la fidalguia provincial a la alta nobleza de Corte. El patriciado urbano. El poder de las élites de letrados. La hora de los poderosos rurales. Otros grupos intermedios. Los grupos populares. Las canonjías doctorales: espacios para la élite y la promoción social. Bibliografía.

Como citar: López-Salazar, A. I. (2021). Los canónigos doctorales en Portugal: orígenes sociales y carreras de una élite eclesiástica (siglos XVI y XVII), en Cuadernos de Historia Moderna, 697-727.

\footnotetext{
1 La investigación para este trabajo ha sido posible gracias a los proyectos de investigación HAR2017-84627-P, PGC2018-093833-B-I00 y PID2019-109168GB-I00.

2 Universidad Complutense de Madrid

ORCID: http://orcid.org/0000-0002-4279-596X

Email: anailo02@ucm.es
} 


\section{Introducción}

Durante la Edad Moderna, los cabildos catedralicios no se mantuvieron como instituciones socialmente homogéneas. Ello se debió a la evolución política y social de los tres siglos, a la diversidad de cabildos y a la variedad de las prebendas. La evolución político-social provocó, probablemente, cierto desinterés de la alta nobleza por las prebendas capitulares, a diferencia de lo que había ocurrido en la Baja Edad Media. Además, no todos los cabildos gozaban del mismo prestigio y disfrutaban de las mismas rentas, por lo que no cabe duda de que hubo cabildos más aristocráticos que otros, bien por su riqueza bien por encontrarse en ciudades de marcada presencia nobiliaria. Finalmente, no todas las prebendas resultaban igualmente apetecibles para los miembros de los estratos sociales más elevados, ya fuese por sus escasas rentas o por encontrarse en ciudades poco interesantes para quienes buscaban el ascenso social o, al menos, el contacto con el poder central o la más alta cultura.

Hace ya treinta años, el añorado Joaquim Romero Magalhães, con la agudeza y penetración que le caracterizaban, apuntó la posibilidad de que los miembros del clero medio portugués, formado fundamentalmente por los canónigos, procediesen de las élites urbanas, de aquella "gente nobre e gente importante" que integraba los gobiernos municipales. Desgraciadamente, la casi total ausencia de estudios sobre los orígenes sociales del clero portugués no ha permitido juzgar si estaba en lo cierto el genial historiador ${ }^{3}$. Se trata de una cuestión de la máxima relevancia para entender la sociedad portuguesa de la Edad Moderna, ya que la caracterización sociológica del clero capitular puede proporcionar luz sobre los grupos sociales de que se nutría y las instituciones utilizadas por las élites y los estratos intermedios en sus estrategias de promoción y perpetuación de los estatus alcanzados. A partir del caso concreto, pero muy significativo, de las canonjías doctorales, intentaremos analizar estas cuestiones que rebasan, con mucho, el marco de los estudios sobre el clero, pues atañen de lleno a una caracterización social de las élites y grupos intermedios portugueses del período moderno.

De todas las prebendas capitulares, las canonjías doctorales presentan características muy específicas, especialmente en el caso portugués. Creadas de manera definitiva en 1560, las canonjías doctorales en Portugal eran, strictu sensu, las de los cabildos antiguos, es decir, aquellos que procedían de la Edad Media ${ }^{4}$. Éstas eran

\footnotetext{
Sobre las élites concejiles, señalaba Romero Magalhães: "Será este grupo da gente nobre um novo grupo de poder, um novo escol político? Como grupo nacional não, pois a solidariedade não ultrapassa os respectivos espaços de mando, embora por igual prezem a sua qualidade de nobres. Mas penso que daqui saem, afinal, os quadros médios da igreja -beneficiados e cónegos-e os que se formam na Universidade e vão depois exercer as magistraturas régias”. Magalhães, J. R.: O Algarve económico: 1600-1773, Lisboa, Estampa, 1993, p. 343. En 2003, Fernanda Olival y Nuno Monteiro advertían de la escasez de estudios sobre la realidad social del clero portugués: Olival, F. y Monteiro, N.: "Mobilidade social nas carreiras eclesiásticas em Portugal (1500-1820)", Análise Social, vol. 37, n. 165 (2003), p. 1239. El mejor estudio de los miembros de un cabildo portugués en la Edad Moderna es el de Silva, H. R.: O cabido da Sé de Coimbra. Os homens e a instituição. 1620-1670, Lisboa, ICS, 2010.

4 Se trataba de los cabildos de las sedes metropolitanas de Braga, Lisboa y Évora y de los de las sedes episcopales de Oporto, Coimbra - que tenía dos doctorales-, Lamego, Viseu, Guarda y Faro.
} 
de patronato regio y su provisión se realizaba de manera centralizada. En las oposiciones, celebradas en la Universidad de Coimbra, votaban los profesores de Prima y Vísperas de las Facultades de Teología, Cánones y Leyes -a los que se unirían desde 1653 los de Medicina- y los profesores de Decreto y Sexto de la Facultad de Cánones. El monarca, patrono de dichas prebendas, presentaba al propuesto por la Universidad al obispo, que le confería la colación canónica ${ }^{5}$.

Muy pronto, las canonjías doctorales quedaron monopolizadas por los ministros del Santo Oficio como inquisidores, diputados (ordinarios y extraordinarios) y fiscales. Desde 1539, éstos contaban con un privilegio papal, llamado del quinquenio, que les eximía del deber de residencia en sus beneficios debido a que, en teoría, estaban ocupados en la defensa de la fe. A diferencia de lo que ocurrió con las canonjías doctorales, las magistrales escaparon al control masivo de los ministros de la fe por dos motivos. En primer lugar, desde 1575, las prebendas magistrales quedaron excluidas del privilegio del quinquenio concedido a la Inquisición y, por lo tanto, sus titulares debían cumplir con el deber de residencia en su beneficio. En segundo lugar, la mayoría de los inquisidores y diputados se habían formado en la Facultad de Cánones $\mathrm{y}$, por ello, no podían presentarse a los concursos de las magistrales, en los que se exigía formación en Teología.

Debido al requisito de la licenciatura en Cánones para acceder a ellas, a la forma de provisión centralizada en la Universidad de Coimbra y a que fueron copadas por inquisidores-diputados y profesores de la Universidad de Coimbra, las canonjías doctorales acabaron en manos de una reducidísima élite de poder con intereses de ámbito nacional. Se trataba de un grupo cuyos objetivos abarcaban todo el reino: ascender de unos cabildos a otros con mayor prestigio y rentas sin residir nunca en ninguno; vincularse a la Inquisición a veces sólo para gozar de sus privilegios; pasar de unas cátedras a otras hasta llegar a las más prestigiosas; alcanzar uno de los dos altos tribunales de justicia -en Oporto o Lisboa-o, mejor aún, el Desembargo do $P a c ̧ o$ o, en su defecto, conseguir un obispado.

Además, las prebendas doctorales escaparon al monopolio que ciertas familias y grupos ejercieron sobre el resto de las canonjías, sobre todo desde mediados del siglo XVI gracias al uso de las resignas in favorem y de las coadjutorías. Ello dio lugar a la aparición de verdaderas dinastías, pues tíos, sobrinos y primos se iban sucediendo en el disfrute de los beneficios capitulares. Nada de ello ocurrió en el caso de las prebendas doctorales. Su provisión por medio de concurso hacía que escapasen a la patrimonialización que permitían coadjutorías y resignas. Ello no quiere decir que no fueran usadas por familias poderosas para cumplir objetivos de promoción y perpetuación social. Lo que ocurre es que los grupos familiares que colocaron a sus miembros en las doctorales tenían, en ocasiones, unos objetivos sociales y políticos de ámbito geográfico nacional y no circunscritos a una determinada ciudad o región.

Por cuestiones de espacio, hemos tenido que limitar nuestro estudio a los siglos XVI y XVII. No obstante, creemos que, en sus rasgos generales, los perfiles sociales aquí presentados puede que pervivieran durante buena parte del XVIII e, incluso, hasta la Revolución Liberal. Desde el punto de vista institucional, la realidad de los canónigos doctorales no cambió sustancialmente desde mediados del XVII: eran en general profesores en la Universidad de Coimbra y miembros del Santo Oficio. La

En algunos casos aislados de principios de la década de 1560 los concursos tuvieron lugar en la Mesa da Consciência, en Lisboa. 
mayoría, no obstante, no hizo carrera inquisitorial, sino que permaneció toda su vida en el cargo de diputado o diputado extraordinario, lo que permitía el desempeño de otros oficios y el disfrute de los privilegios inquisitoriales, el más importante de los cuales, para ellos, era el de percepción de los frutos de sus beneficios eclesiásticos sin cumplir con la obligación de residencia.

\section{Un apunte metodológico}

El objetivo de este trabajo es presentar un análisis de las carreras en el ámbito eclesiástico, universitario y político de los canónigos doctorales portugueses durante los siglos XVI y XVII, de sus procedencias geográficas y, sobre todo, de sus orígenes sociales. Este último aspecto, sin duda el más complejo, nos obliga a realizar varias precisiones metodológicas ${ }^{6}$.

En primer lugar, debemos tener en cuenta que, a diferencia de otros trabajos sobre los miembros de una catedral concreta, nosotros estamos estudiando un conjunto de personas que circularon por todos los cabildos portugueses y que, por ello mismo, tuvieron procedencias geográficas muy dispares que iban desde la frontera con Galicia a las tierras del Bajo Alentejo. Ello quiere decir que debemos estar especialmente atentos a lo que significan los criterios de clasificación en el contexto local de nacimiento o de residencia de cada uno de los canónigos doctorales. Los conceptos utilizados en dos lugares pueden ser los mismos, pero hacer referencia a realidades diferentes. Y, al revés, distintas realidades pueden nombrarse utilizando el mismo término. Hace casi cien años, Marc Bloch nos advertía de la necesidad de confrontar cada término con todo lo que lo rodeaba, es decir, la época, la región y los propios usos del autor ${ }^{7}$. Más recientemente, Jean-Pierre Dedieu ha vuelto a llamar la atención sobre la necesidad de situar lo observado en el contexto local para poder comprender qué función desempeñaba una honra o distinción en el grupo al que pertenecía el individuo que la recibía ${ }^{8}$.

En segundo lugar, resulta necesario realizar una precisión conceptual. En el Portugal moderno, se fue produciendo un proceso de ensanchamiento de la base de la nobleza, que llevó aparejada una desvalorización de la categoría social de "noble". Por ello, a pesar de que la distinción básica de la sociedad moderna portuguesa fuese la que existía entre nobles y mecánicos, no resulta posible elaborar un estudio de los orígenes sociales de una élite eclesiástica basándonos únicamente en ese binomio, porque llegaríamos al poco sorprendente resultado de que casi todos los canónigos doctorales procedían de familias que podían ser consideradas nobles o que, al menos, vivían "a ley de nobleza", por usar la expresión de la época. De manera que hemos tenido que recurrir a criterios mucho más complejos de clasificación social, con todos los riesgos que ello implica.

\footnotetext{
Muy útiles resultan las recientes apreciaciones metodológicas de Dedieu, J.-P.: "La importancia del actor. Reflexiones sobre el porvenir de la Historia Social", Estudis (en prensa).

Bloch, M.: Apología para la historia o el oficio del historiador, México, FCE, 2001, pp. 159-160.

8 Dedieu, J.-P.: "Hábitos o condecoraciones. ¿Unos instrumentos para la vertebración de la clase política?", en López-Salazar, A. I.; Figueirôa-Rêgo, J., y Olival, F. (coords.): Honra e sociedade no mundo ibérico e ultramarino. Inquisição e Ordens Militares, Lisboa, Caleidoscópio, 2013, p. 312.
} 
Hemos clasificado a cada uno de los canónigos en función de los tres criterios o factores que, según Labrousse, se podían utilizar para definir las clases o los estamentos sociales: el nacimiento, la riqueza y la función ${ }^{9}$. Debido a la primacía de la familia sobre el individuo en la sociedad moderna, hemos intentado situar a cada uno de los canónigos en contextos familiares amplios, estudiando no sólo a sus padres, abuelos y bisabuelos -cuando tal era posible- sino también a sus hermanos, primos y sobrinos, para intentar conocer las estrategias familiares a las que respondía la formación académica y la carrera de los doctorales, así como los procesos de movilidad social en los que estaban insertos. Con respecto a la riqueza, nos hemos tenido que contentar con apreciaciones subjetivas de los contemporáneos, debido al tipo de fuentes utilizadas. No obstante, no por subjetivas resultan irreales, pues nos permiten conocer cómo percibían los convecinos la situación económica de las familias de los canónigos. Finalmente, prestamos atención a la función, es decir, al desempeño de cargos y oficios, tanto honoríficos como remunerados, algunos de los cuales requerían formación letrada.

No obstante, no podemos olvidar que cualquier clasificación supone una reducción de lo complejo a lo simple y que, en muchos casos, resulta sumamente difícil clasificar a las personas, individuales e irrepetibles, en categorías sociales. Porque, a pesar de la homogamia, no existen dos familias iguales. Porque un mismo individuo puede tener diferentes niveles de fortuna a lo largo de su vida y desempeñar diversos tipos de cargos y oficios. Y, finalmente, porque las personas pueden optar por definirse y presentarse de una manera $u$ otra en función de las circunstancias.

\section{Fuentes}

El estudio de los canónigos doctorales presenta ciertas especificidades. Por ello, no siempre se puede recurrir a las fuentes usadas para el análisis de los orígenes sociales de los demás miembros de los cabidos catedralicios. Por un lado, dado que se trataba de canonjías de provisión centralizada, los doctorales pocas veces procedían de las ciudades donde se encontraban sus cabildos. Además, a diferencia de los demás canónigos y dignidades, los doctorales raramente residieron en sus canonjías, salvo en los casos de Coimbra y, en menor medida, de Lisboa. Por ello, las fuentes locales no son útiles, salvo en Coimbra y Lisboa. En este último caso, además, los Index das notas de vários tabeliães de Lisboa, que extractan parte de la información notarial de la ciudad, tampoco han proporcionado información de relieve sobre el tema que nos interesa ${ }^{10}$.

La propia documentación capitular tampoco resulta útil en muchos casos para conocer los orígenes sociales de los doctorales, debido a que hasta la década de 1620 no se comenzaron a implantar en las catedrales portuguesas los estatutos de limpieza de sangre. Como es sabido, en 1621, el cabildo de Coimbra consiguió un breve papal que excluía a los cristianos nuevos. A partir de ahí, el requisito de limpieza de sangre se fue extendiendo a otras corporaciones capitulares, como las de Evora y Oporto

\footnotetext{
Labrousse, E.: "Conclusion”, en Odres et classes, Paris-La Haye, EPHE - Mouton, 1973, pp. 267-269.

10 Index das notas de vários tabeliães de Lisboa entre 1580 e 1747, Lisboa, Biblioteca Nacional, 1930-1949, 4 vols.
} 
(ambas en 1625), Viseu y Lisboa (1628), Lamego (en 1638), Elvas (en 1641) y Faro (en 1641, si bien no se aplicó hasta 1698) ${ }^{11}$.

Además de haber exigido el requisito de limpieza de sangre de manera tardía con respecto a Castilla, algunos cabildos no se mostraron muy diligentes a la hora de realizar las pruebas de limpieza de los nuevos prebendados. Sólo el de Coimbra efectuó las habilitaciones de limpieza de sangre de prácticamente todos los que poseyeron sus dos canonjías doctorales a partir de $1621^{12}$. Sin embargo, en otros cabildos apenas contamos con documentación relativa a estos prebendados. Así, en Lamego y Viseu sólo tenemos cuatro habilitaciones de doctorales del XVII, en Braga tres, en Évora y Oporto una y en Faro ninguna.

Se imponía, por lo tanto, recurrir a otro tipo de fuentes que no fuesen las locales. Existen las pruebas de limpieza del colegio mayor de San Pedro de la Universidad de Coimbra. Por él pasaron veintisiete futuros doctorales de los siglos XVI y XVII, y se conservan las pruebas de limpieza de veintitrés de ellos. El problema radica en que suponen un porcentaje reducido del total de los canónigos y en que la información que proporcionan resulta, a veces, muy escueta ${ }^{13}$.

Era necesario acudir a una fuente que proporcionase información sustanciosa, que existiese al menos desde el último cuarto del XVI y que permitiese el estudio de casi todos los canónigos doctorales, independientemente del cabildo y colegio mayor a los que hubiesen pertenecido. Las pruebas de limpieza de sangre de la Inquisición eran las únicas que cumplían estos requisitos. Además, junto a las de los propios canónigos, en algunos casos existen las de parientes cercanos, que también integraron el Santo Oficio como familiares o ministros. En total, he trabajado con ochenta pruebas de limpieza de sangre realizadas por la Inquisición a los doctorales y sus parientes. La información procedente de estos documentos se ha completado con otros expedientes de instituciones capitulares (Lamego y Évora) y de la Câmara Eclesiástica de Évora ${ }^{14}$.

Asimismo, he recurrido a la documentación de las instituciones centrales de la Corona, donde quedaban registradas las mercedes reales, como los libros de la Chancillería Regia de todos los reinados comprendidos entre João III y Pedro II, los del Registro General de Mercedes y los de matrículas de la Casa Real ${ }^{15}$. La información procedente de estas fuentes se ha completado con la que contienen los nobiliarios,

11 Olival y Monteiro, op. cit. (nota 3), p. 1222. Silva, H. R.: O clero catedralício portugués e os equilíbrios sociais do poder (1564-1670), Lisboa, UCP-CEHR, 2013, pp. 151-152. Silva, H. R.: "O cabido", en Paiva, J. P. (coord.): História da Diocese de Viseu, Viseu-Coimbra, Diocese de Viseu-Imprensa da Universidade de Coimbra, 2016, vol. 2, p. 245. La información de Faro procede de las propias pruebas de limpieza de sangre conservadas en el archivo del cabildo.

12 A excepción de António Leitão Homem. No obstante, la de João de Carvalho sólo contiene la procuración hecha a Gonçalo Alvo Godinho para ser colado en la canonjía, según Silva, A. M. Dias da: "Processos para Dignidades e beneficiados da Sé de Coimbra: origem geográfica”, en Casa Nobre: Um Património para o Futuro, Actas - $3^{\circ}$ Congresso Internacional, Arcos de Valdevez, Município de Arcos de Valdevez, 2013, p. 372.

13 Además, el estallido de la pandemia de coronavirus en diciembre del 2019 no ha permitido consultar buena parte de la documentación del Colegio de San Pedro de Coimbra.

14 La documentación del cabildo de la catedral de Lamego se encuentra en el Arquivo Nacional da Torre do Tombo, la del cabildo de Évora en la propia institución capitular y la de la Cámara Eclesiástica de Évora en el Arquivo Distrital de Évora. Agradezco a Antonio Díaz que me proporcionase la información de la prueba de limpieza de sangre de Gonçalo Alvo Godinho para ingresar en el cabildo de Évora.

15 La documentación de la Chancelaria Regia (CHR), del Registo Geral de Mercês y de la Casa Real se encuentra en el Arquivo Nacional da Torre do Tombo. Para los fueros (foros) y oficios de la Casa Real he consultado el Inventário dos Livros de Matrícula da Casa Real, Lisboa, 1911-1917. 
especialmente la Pedatura Lusitana de Cristóvão Alão de Morais, y obras histórico-geográficas como la Corografia portuguesa del padre António Carvalho da Costa. Además, este trabajo se ha beneficiado enormemente de las grandes obras de investigación histórica llevadas a cabo en el siglo XVIII: los catálogos de los colegiales de San Pedro y San Pablo, elaborados por Manuel Pereira da Silva Leal y José Barbosa respectivamente, la Bibliotheca Lusitana de Diogo Barbosa Machado y el Memorial de ministros de fray Luís de São Bento y fray António Soares ${ }^{16}$. Finalmente, nos han sido de gran utilidad los índices y catálogos de alumnos y profesores de la Universidad de Coimbra elaborados por el profesor Manuel Augusto Rodrigues, antiguo director del archivo de esta institución ${ }^{17}$.

Un trabajo basado en las pruebas de limpieza de sangre, tanto de la Inquisición como de los cabildos o de los colegios mayores, nos obliga a preguntarnos por la validez de estas fuentes para nuestro estudio. Como han puesto de manifiesto los profesores Enrique Soria y Antonio Díaz en el caso de Castilla, los expedientes podían estar manipulados para probar la limpieza de sangre del pretendiente al cargo y, de hecho, en Castilla numerosos descendientes de conversos ingresaron en instituciones que exigían este requisito ${ }^{18}$. Creemos que esta cuestión resulta menos relevante en el caso de Portugal, porque aquí todo parece indicar que los matrimonios mixtos entre cristianos viejos y nuevos fueron muchos menos que en Castilla y los conversos se mantuvieron como un grupo separado, bien definido y percibido claramente como tal. Sea como fuere, la cuestión de la manipulación en lo que atañe a la limpieza no afecta a nuestro propósito ni invalida estas fuentes para nuestro estudio. $\mathrm{Si}$, como señaló Jean-Pierre Dedieu, las pruebas de limpieza reflejan el poder social del pretendiente, resultan especialmente útiles para este trabajo, puesto que lo que nos proponemos es, precisamente, conocer los orígenes sociales de los canónigos doctorales ${ }^{19}$. Como las categorías sociales, a diferencia de las jurídicas, son una abstracción que dependen de la percepción de los contemporáneos, una fuente que refleja dicha percepción subjetiva de los vecinos de un candidato a un cargo, oficio o beneficio resulta muy útil para el presente trabajo. Además, las pruebas de limpieza son ilustrativas del medio social de procedencia del candidato no sólo por lo que dicen de él los testigos, sino por la propia extracción social de las personas llamadas a declarar en cada caso.

16 Morais, C. Alão de: Pedatura Lusitana, Porto, Fernando Machado, 1943-1948, 12 vols. Costa, A. Carvalho da: Corografia portuguesa e descripçam topográfica do famoso reyno de Portugal, Lisboa, Valentim da Costa Deslandes, 1706-1712, 3 vols. Leal, M. Pereira da Silva: "Catalogo chronologico dos collegiaes e porcionistas do Collegio de S. Pedro, desde o anno 1574 em que foy restaurado, até o presente de 1725", en Colleção dos Documentos e Memorias da Academia da História Portuguesa, Lisboa, Pascoal da Sylva, 1725, número XXX. Barbosa, J.: "Memórias do Collégio Real de S. Paulo da Universidade de Coimbra e dos seus Collegiaes e Porcionistas", en Colleção dos Documentos e Memorias da Academia da História Portuguesa, Lisboa, Pascoal da Sylva, 1727, número XXIV. Machado, D. Barbosa: Bibliotheca Lusitana, Lisboa, António Isidoro da Fonseca, Ignacio Rodrigues e Francisco Luiz Ameno, 1741-1759, 4 tomos. São Bento, L. y Soares, A.: Memorial de ministros: catálogo alfabético dos ministros de letras, estudo e transcrição de Nuno Camarinhas, Lisboa, BNP, 2017.

17 Rodrigues, M. A. (dir.): Memoria Professorum Universitatis Conimbrigensis, Coimbra, Arquivo da Universidade de Coimbra, 2003, vol. 1.

18 Soria Mesa, E.: La realidad tras el espejo: ascenso social y limpieza de sangre en la España de Felipe II, Valladolid, Universidad de Valladolid, 2016, y "Los estatutos municipales de limpieza de sangre en la Castilla moderna. Una revisión crítica", Mediterranea - ricerche storiche, 27 (2013), pp. 9-36.

19 Dedieu, J. P.: "Limpieza, poder y riqueza. Requisitos para ser ministro de la Inquisición. Tribunal de Toledo, siglos XVI-XVII", Cuadernos de Historia Moderna, 14 (1993), p. 44. 


\section{Carreras eclesiásticas y políticas}

Las canonjías doctorales se empezaron a instituir en los cabildos antiguos a partir de 1560 , salvo en los casos de Évora y Silves, donde existían desde antes ${ }^{20}$. Hasta finales del siglo XVI, estos canónigos apenas se diferenciaban de los demás prebendados de sus cabildos y aún no se habían constituido en una élite con objetivos, intereses y vinculaciones de carácter nacional. Ello era así porque las prebendas doctorales aún no habían sido monopolizadas por los inquisidores y profesores de Coimbra y, por lo tanto, sus poseedores no constituían un grupo abrumadoramente absentista, al menos hasta la muerte de don Henrique. De hecho, de los trece doctorales que obtuvieron sus canonjías antes de la muerte del cardenal en 1580, sólo cuatro desempeñaron cargos en el Santo Oficio, y tres de ellos lo hicieron en las mismas ciudades en las que tenían sus beneficios ${ }^{21}$. Además, a diferencia de lo que ocurriría más tarde, los miembros de la Inquisición que ocuparon doctorales hasta 1580 realmente hicieron carrera en el tribunal y no permanecieron como simples diputados, salvo en un caso ${ }^{22}$.

El hecho de que los doctorales de tiempos de don Henrique se asemejen más a los otros canónigos que a los doctorales de los siglos siguientes se manifiesta en algunos aspectos. En primer lugar, en algo más de la mitad de ellos se aprecia cierta vinculación regional, de modo que ocupan las canonjías en las sedes de las diócesis de las que son originarios. En segundo lugar, algunos están vinculados a los obispos y desempeñan cargos diocesanos, algo prácticamente impensable en el siglo XVII. António de Carvalho fue oidor del tribunal eclesiástico de Braga; Luís Lopes de Almeida, provisor y vicario general del obispado de Oporto; Manuel Seabra, visitador del mismo obispado de Oporto, y Rodrigo de Malafaia, oidor del tribunal eclesiástico de Viseu y, más tarde, vicario y provisor del obispado. A partir de finales del XVI, los doctorales dejarán de proceder de las diócesis en las que tienen su prebenda y, debido al absentismo generalizado, no desempeñarán cargos en la administración diocesana.

En un primer momento, buena parte de los doctorales estaban vinculados a don Henrique. En algunos casos, la vinculación era directa. Así, António de Carvalho, doctoral de Braga, era secretario del cardenal-infante, desembargador de su casa y oidor de la legacía. Por su parte, António de Mendonça desempeñaba el oficio de capellán del rey cuando obtuvo la doctoral de Lisboa. En otros casos, se trataba de ministros de la Inquisición y, por lo tanto, criaturas del cardenal-infante. Esta conexión con don Henrique explica que algunos de ellos no realizaran oposición para obtener la prebenda, como António de Carvalho, doctoral de Braga, y Sebastião Vaz, doctoral de Coimbra.

Tras la muerte del cardenal don Henrique y hasta finales del siglo XVI se empiezan a definir las características clásicas de estos canónigos de oficio que ya no

20 Las canonjías doctorales de Évora y Silves se crearon en virtud de la bula de Alejandro VI de 1496. Desconozco en qué momento exacto se erigieron estas prebendas en dichos cabildos. Sólo sé que ya existía en Évora en 1537, cuando la catedral fue visitada por el cardenal-infante don Alfonso.

21 Diogo Mendes de Vasconcelos, canónigo de Évora desde 1557, fue nombrado inquisidor de dicha ciudad en 1564. Simão Vaz era inquisidor de Coimbra y canónigo doctoral de la misma ciudad. António de Mendonça, doctoral de Lisboa desde enero de 1579, accedió al Consejo General en agosto de dicho año. La única excepción fue Rodrigo Aires Monteiro, doctoral de Guarda desde 1566 y diputado de Lisboa desde 1576. No obstante, en 1581 renunció a la canonjía de Guarda para pasar a ocupar la doctoral de Lisboa.

22 Rodrigo Aires Monteiro, doctoral de Guarda y de Lisboa, apenas sirvió como diputado del tribunal de Lisboa, sin ascender nunca al oficio de inquisidor. 
cambiarán sustancialmente a lo largo de la centuria siguiente. En los últimos veinte años del Quinientos y en la primera mitad del Seiscientos se va perfilando esta élite de manera cada vez más nítida. Los doctorales dejan de proceder de las diócesis en las que poseerán sus prebendas y de cumplir con el deber de residencia. Irá aumentando cada vez más el número de aquellos que sirven en el Santo Oficio y que, por ello, pueden ampararse en el privilegio inquisitorial de non residendo en sus beneficios. El porcentaje de los que integran la Inquisición pasa del $60 \%$ en los últimos años del XVI al $81 \%$ en la primera mitad del XVII y al $91 \%$ en la segunda mitad de dicho siglo. Por su parte, el porcentaje de los que desempeñan funciones docentes en la Universidad de Coimbra también ascenderá, pasando del $40 \%$ a finales del siglo XVI al $70 \%$ en la segunda mitad del siglo XVII. En el XVIII, todos los doctorales portugueses ejercieron, en algún momento u otro de sus vidas, de profesores de la Universidad de Coimbra.

La aparición de la figura del doctoral-profesor irá acompañada de una modificación en el perfil de los que desempeñaban cargos en el Santo Oficio. Desde mediados del siglo XVII, la mayoría de los ministros del Santo Oficio que obtuvieron canonjías doctorales no pasaron de diputados, normalmente del tribunal de Coimbra, sin jamás ascender al oficio de inquisidor o al de diputado del Consejo General. Se trata de una tendencia que hace preludiar lo que será el siglo XVIII, cuando el $88 \%$ de los canónigos doctorales limitaron su carrera inquisitorial al oficio de diputado, frecuentemente con carácter extraordinario, es decir, sin sueldo pero con derecho a gozar del privilegio inquisitorial de non residendo ${ }^{23}$.

Cuadro 1. Vinculación de los canónigos doctorales al Santo Oficio

\begin{tabular}{|l|c|c|c|c|}
\hline & $\begin{array}{c}\text { Canónigos } \\
\text { doctorales }\end{array}$ & $\begin{array}{c}\text { Canónigos doc- } \\
\text { torales-ministros } \\
\text { del Santo Oficio }\end{array}$ & $\begin{array}{c}\text { Con carrera inquisitorial } \\
\text { (inquisidores o diputados } \\
\text { del Consejo General) }\end{array}$ & $\begin{array}{c}\text { Únicamente } \\
\text { diputados de } \\
\text { los tribunales } \\
\text { de distrito }\end{array}$ \\
\hline $1561-1600$ & 23 & 10 & 6 & 4 \\
\hline $1601-1650$ & 27 & 22 & 11 & 11 \\
\hline $1651-1700$ & 31 & 28 & 9 & 19 \\
\hline $1701-1750$ & 18 & 18 & 1 & 17 \\
\hline $1751-1800$ & 31 & 28 & 2 & 26 \\
\hline
\end{tabular}

Fuentes: véase el apartado correspondiente en el cuerpo del texto.

Al mismo tiempo, estos eclesiásticos se irán convirtiendo en unos verdaderos expertos a la hora de presentarse a los concursos para las canonjías, de manera que irán pasando de unos cabildos a otros para intentar conseguir siempre prebendas con mayores rentas, lo que demuestra que pierden toda vinculación con sus cabildos más allá de la económica. Así, en tiempos de don Henrique, la inmensa mayoría de los que obtenían una canonjía doctoral permanecían en ella hasta el final de sus días o hasta que alcanzaban algún obispado. Sin embargo, en el XVII, a la vez que

23 López-Salazar, A. I.: "Una oligarquía eclesiástica en Portugal durante el Antiguo Régimen: catedráticos, canónigos e inquisidores”, Libros de la Corte, monográfico 6, año 9 (2017), p. 182. 
dejan de residir en sus prebendas, va surgiendo la figura del canónigo itinerante, que pasa por varios cabildos sin residir en ninguno. En la segunda mitad del siglo XVII, la mayoría de los canónigos no se contentaban con permanecer en el primer cabildo cuya canonjía habían conseguido, sobre todo si se trataba de una prebenda de inicio de carrera, con rentas reducidas. Llegará a darse el caso de un eclesiástico que disfrutará sucesivamente de cinco canonjías doctorales ${ }^{24}$. En el siglo XVIII, esta tendencia a pasar de unas prebendas a otras se mantendrá, aunque de manera algo más moderada.

Cuadro 2. Número de prebendas doctorales poseídas por cada canónigo (nunca en acumulación)

\begin{tabular}{|l|r|r|r|r|r|c|}
\hline & 1 & 2 & 3 & 4 & 5 & $\begin{array}{c}\text { Total canónigos } \\
\text { doctorales }\end{array}$ \\
\hline $1561-1600$ & 20 & 2 & 1 & - & - & 23 \\
\hline $1601-1650$ & 18 & 6 & 3 & - & - & 27 \\
\hline $1651-1700$ & 11 & 10 & 4 & 5 & 1 & 31 \\
\hline $1701-1750$ & 9 & 7 & 2 & - & - & 18 \\
\hline $1751-1800$ & 14 & 10 & 6 & 1 & - & 31 \\
\hline
\end{tabular}

Fuentes: véase el apartado correspondiente en el cuerpo del texto.

Entre los siglos XVI y XVIII, la mayoría de los canónigos doctorales que accedieron a la Universidad y al Santo Oficio terminaron sus carreras en estas instituciones. Hubo, sin embargo, un tercio que logró ascender a los altos tribunales de justicia (la Relação do Porto y la Casa da Suplicação) e incluso al Desembargo do Paço, el más importante Consejo real. En algunos casos, ello no suponía abandonar la carrera docente, al menos en un primer momento, dado que el oficio de desembargador podía ejercerse durante las vacaciones académicas.

Mucho menos significativo fue el número de doctorales que lograron alcanzar un obispado o que, al menos, fueron elegidos para ello por el monarca durante la Guerra de Restauración, cuando la Santa Sede se negó a confirmar los eclesiásticos presentados por el rey portugués. En total, en los tres siglos hubo catorce doctorales consagrados obispos, además de al menos tres que no llegaron a ser confirmados debido a la guerra. Ninguno de ellos logró una mitra poderosa y la mayoría tuvieron que conformarse con las ultramarinas (Ceuta, Angra o Bahía) o las nuevas (creadas en el XVI o en el XVIII). Hubo algún afortunado que alcanzó la de Viseu, un obispado que en el siglo XVII tenía unas rentas que podíamos considerar intermedias ${ }^{25}$. No obstante, resultaría erróneo considerar que la canonjía doctoral había constituido el paso previo que les permitió acceder a las mitras. En la mayoría de los casos, el

24 Se trató de Pedro Álvares Garrido, canónigo doctoral de Viseu (1685), Lamego (1685), Guarda (1691), Porto (1695) y Coimbra (1701).

25 Sobre las rentas de los obispados a mediados del siglo XVII, vid. Paiva, J. P.: "D. Fr. Luís da Silva e a gestão dos bens de uma mitra. O caso da diocese de Lamego (1677-85)", en Ramos, L. A. Oliveira, Ribeiro, J. Martins, e Polónia, A. (coords.): Estudos de homenagem a João Francisco Marques, Porto, Faculdade de Letras da Universidade do Porto, 2001, vol. II, pp. 251-252. 
Santo Oficio supuso el eslabón verdaderamente relevante que les permitió adquirir la notoriedad, los servicios y los vínculos necesarios para la posterior promoción a una de las mitras. De hecho, durante los siglos XVI y XVII, todos los doctorales que obtuvieron obispados habían sido habilitados para servir en el Santo Oficio; todos salvo uno desempeñaron oficios en el tribunal y la mayoría no permaneció como simple diputado, sino que realizó carrera inquisitorial hasta alcanzar en la mitad de los casos el Consejo General ${ }^{26}$.

\section{Orígenes geográficos}

Antes de proceder al análisis de los orígenes sociales de los canónigos doctorales, puede resultar revelador conocer los geográficos, pues en este aspecto se diferencian considerablemente de los demás miembros de los cabildos. Como ha puesto de manifiesto la historiografía sobre las instituciones capitulares, la mayoría de sus miembros procedían bien de la propia diócesis bien de las regiones circundantes ${ }^{27}$. Por el contrario, los canónigos doctorales, sobre todo a partir de finales del siglo XVI, carecían generalmente de cualquier vínculo previo con las ciudades en las que se encontraban sus prebendas.

Como podría esperarse, la mayoría de los canónigos doctorales proceden de las zonas más densamente pobladas y de aquellas que experimentaron mayor crecimiento demográfico entre 1527 y 1706 , fechas para las cuales la historiografia portuguesa sobre la población cuenta con datos relativamente seguros. De los ochenta y un doctorales que ingresaron en los cabildos, veintiuno $(25,92 \%)$ eran originarios de la provincia de Entre Douro e Minho y veintitrés $(28,39 \%)$ de la de Estremadura ${ }^{28}$. A principios del XVIII, ambas concentraban el 22,3\% y 20,7\% de los fuegos portugueses. Sin duda, el considerable número de doctorales de Estremadura se debe a la relevancia en términos demográficos y políticos de la ciudad de Lisboa y a la importancia religiosa y cultural de la de Coimbra, de las que procedían mayoritariamente. De la provincia de Beira -fundamentalmente de las comarcas de Lamego y Viseu-

26 La Inquisición realizó las pruebas de limpieza de sangre de Manuel Seabra, futuro obispo de Ceuta, en las que se afirmaba que era limpio. No obstante, no llegó a desempeñar ningún cargo en el Santo Oficio. Sobre la Inquisición como cantera de futuros obispos, sobre todo en los siglos XVI y XVII, vid. Bethencourt, F.: La Inquisición en la época moderna. España, Portugal, Italia, siglos XV-XIX, Madrid, Akal, 1997, pp. 160-161; Paiva, J. P.: Os bispos de Portugal e do Império: 1495-1777, Coimbra, Imprensa da Universidade de Coimbra, 2006, pp. 424-425.

27 Así, por ejemplo, en el caso de Córdoba, bien estudiado por Díaz Rodríguez, más de la mitad de los capitulares eran originarios del propio reino de Córdoba y otro porcentaje considerable de las regiones adyacentes. Por su parte, en el cabildo de Murcia en el siglo XVII, algo más de la mitad de los capitulares provenían de dicho reino. Díaz Rodríguez, A. J.: El clero catedralicio en la España Moderna: los miembros del Cabildo de la Catedral de Córdoba (1475-1808), Murcia, Universidad de Murcia, 2012, pp. 129-130. Irigoyen López, A.: Entre el cielo y la tierra, entre la familia y la institución. El cabildo de la catedral de Murcia en el siglo XVIII, Murcia, Universidad de Murcia, 2001, pp. 228-229.

28 Debido a que nuestros datos se refieren a los siglos XVI y XVII, hemos seguido la agrupación de las comarcas en provincias de Hespanha y hemos integrado los de Coimbra y Esgueira en la provincia de Estremadura y los de Setúbal en la de Alentejo. No obstante, tengamos presente que la división provincial fue cambiando y que, a principios del siglo XVIII, las comarcas de Coimbra y Esgueira pertenecían a la provincia de Beira y la de Setúbal a la de Estremadura. Costa, op. cit. (nota 16). Hespanha, A. M.: As vésperas do Leviathan. Instituições e poder político. Portugal-séc. XVII, Coimbra, Almedina, 1994. 
eran originarios diecisiete doctorales $(20,98 \%)$ y catorce $(17,28 \%)$ de la de Alentejo. De nuevo, estas cifras están en consonancia con las del porcentaje total de población portuguesa de ambas regiones. A principios del XVIII, Beira -incluida ya entonces la comarca de Coimbra- concentraba el 30,5\% de los fuegos portugueses, según José Vicente Serrão, o el 21,6\%, de acuerdo con Teresa Rodrigues. Por su parte, el Alentejo contaba con el 14,9\% o el 18,7\% según Serrão y Rodrigues, respectivamente. Por lo tanto, como vemos, los canónigos doctorales procedían de las zonas más pobladas $\mathrm{y}$, además, de aquellas que experimentaron mayor crecimiento entre la década de 1530 y 1700 , es decir, las del litoral ${ }^{29}$.

Cuadro 3. Orígenes geográficos de los doctorales portugueses. Siglos XVI y XVII

\begin{tabular}{|l|r|r|r|}
\hline \multicolumn{1}{|c|}{ Provincia } & $\begin{array}{r}\text { Porcentaje de po- } \\
\text { blación en 1527 }\end{array}$ & $\begin{array}{c}\text { Porcentaje de po- } \\
\text { blación en 1706 }\end{array}$ & $\begin{array}{c}\text { Porcentaje de doc- } \\
\text { torales naturales de } \\
\text { la provincia }\end{array}$ \\
\hline Entre Douro e Minho & 19,5 & $22,3 / 23,4$ & 25,92 \\
\hline Tras-os-Montes & 12,6 & $8,7 / 9,6$ & 1,23 \\
\hline Estremadura & 23,2 & $20,7 / 23,8$ & 20,39 \\
\hline Beira & 23,9 & $30,5 / 21,6$ & 17,28 \\
\hline Alentejo & 17,3 & $14,9 / 18,7$ & 0 \\
\hline Algarve & 3,5 & $2,8 / 2,9$ & \\
\hline
\end{tabular}

Fuentes: para los doctorales, véase el apartado correspondiente en el cuerpo del texto. Los datos de la población del reino proceden de Serrão, op. cit. (nota 29, 1996) y Rodrigues, op. cit. (nota 29), coincidentes en relación con 1527. En la columna relativa al porcentaje de población portuguesa de 1706, los primeros datos son los de Serrão y los segundos los de Rodrigues.

La mayoría de los canónigos doctorales habían nacido en las ciudades cabezas de comarca (correição o ouvidoria) o en otras tan relevantes como aquéllas, si bien resulta necesario tomar estos datos con cierta precaución dado que puede ocurrir que, en algún caso, las fuentes consultadas incurran en alguna generalización y señalen como lugar de nacimiento la sede del concejo y no las zonas rurales. Aun con tales salvedades, se aprecia, también en este aspecto, la macrocefalia de Lisboa tan señalada por la historiografía portuguesa ${ }^{30}$. A principios del siglo XVIII, la ciudad concentraba, sin su término, al 4,9\% de la población total del país y en ella nacieron entre nueve y once de los canónigos doctorales de los siglos XVI y XVII. Tras ella

29 Para los datos de la población portuguesa en los siglos XVI y XVII y su distribución por provincias me baso en Hespanha, op. cit. (nota 28), pp. 61-85; Serrão, J. V.: "O quadro humano", en Hespanha, A. M. (coord.): O Antigo Regime (1620-1807), Lisboa, Editorial Estampa, 1993, pp. 49-69; Serrão, J. V.: "População e rede urbana nos séculos XVI-XVIII", en Oliveira, C. (dir.): História dos municípios e do poder local (dos finais da Idade Média à União Europeia), Lisboa, Círculo de Leitores, 1996, pp. 63-77; Rodrigues, T.: “As vicissitudes do povoamento nos séculos XVI e XVII”, en Eadem (coord.): História da população portuguesa. Das longas permanências à conquista da modernidade, CEPESE e Edições Afrontamento, 2009, pp. 159-246.

30 Según Nuno Camarinhas, el 20,9\% de los magistrados regios que ejercieron entre 1620 y 1800 procedían de Lisboa. Camarinhas, N.: Juízes e administração da justiça no Antigo Regime: Portugal e o império colonial, séculos XVII e XVIII, Lisboa, FCG-FCT, 2010, p. 139. 
destacan, como era de esperar, las ciudades de Oporto, de donde son originarios cinco, y Coimbra, de donde eran naturales cuatro o cinco. La mayoría de los restantes proceden también mayoritariamente de capitales de corregimiento, como Lamego (cuatro), Setúbal (entre dos y cuatro), Viseu (tres), Braga (tres) y Guimarães, Évora y Vila Viçosa (con dos o tres cada una), o de villas muy destacadas dentro de sus comarcas, como Serpa (con tres). De hecho, algo más del 60\% de los canónigos doctorales habían nacido en las ciudades cabezas de comarca.

Por lo tanto, los doctorales portugueses son un grupo de origen urbano, lo que se debe a dos motivos. En primer lugar, según José Vicente Serrão, Portugal era, durante los siglos XVI y XVII, un país relativamente urbanizado, si se tiene únicamente en cuenta el criterio del tamaño, lo que, por otra parte, no deja de presentar problemas. A pesar de ellos, si se consideran como urbanos los núcleos de población de más de 1.000 fuegos, el $18 \%$ de la población portuguesa viviría en ciudades a principios del siglo XVIII (1706). Además, según esos criterios, Portugal contaría con cuarenta núcleos de población considerados urbanos, al menos desde el punto de vista cuantitativo. Si fuésemos más estrictos con las cifras y considerásemos como urbanos los aglomerados de 2.500 fuegos, la tasa de urbanización sería del 10,3\% y el número de agregados urbanos de diez ${ }^{31}$. Ninguno de ellos se situaría en el Algarve, pues el reino experimentó un proceso de ruralización desde finales del siglo XVI, descrito por Romero Magalhães ${ }^{32}$. Este hecho, unido a su escasa población, explica la ausencia de canónigos doctorales originarios del Algarve.

En segundo lugar, el origen urbano de los doctorales se encuentra estrechamente relacionado con los estratos sociales de los que proceden, como veremos en el siguiente apartado. Finalmente, dado que debían contar con los grados de doctor o licenciado en Derecho, era necesario que tuviesen estudios preuniversitarios y tales sólo podían adquirirse en núcleos de cierta entidad, bien en alguna escuela de gramática, bien en los colegios de la Compañía de Jesús, bien con un preceptor privado.

\section{Orígenes sociales}

De los ochenta y un canónigos doctorales de los siglos XVI y XVII, desconocemos los orígenes sociales de dieciséis de ellos, la mayoría de los cuales accedieron a los cabildos en el siglo XVI. Se trata del momento en el que las fuentes son más escasas, debido a que ningún cabildo contaba con estatuto de limpieza de sangre, muchos canónigos no ingresaban en el Santo Oficio, la Inquisición no realizaba pruebas a todos sus miembros o éstas no se han conservado. Para el estudio de los demás, hemos recurrido a unas categorías sociales que no deben considerarse como compartimentos cerrados. Los miembros de una misma familia podían integrarse en categorías diferentes lo que ocurre, sobre todo, en el caso de los estratos intermedios de la élite (principales, ciudadanos, poderosos rurales, oligarquías letradas). No obstante, en aras de la claridad, hemos decidido agrupar a los doctorales cuyos orígenes sociales conocemos en siete grupos (gráfico 1): la nobleza titulada, la fidalguia -tanto provincial como de Corte-, las élites urbanas (patriciado urbano o ciudadanos), los grandes letrados, los poderosos rurales, las

\footnotetext{
Serrão, op. cit. (nota 29, 1996).

Magalhães, op. cit. (nota 3 ).
} 
clases medias (escribanos, secretarios, abogados, gentes que servían oficios públicos, mercaderes, etc.) y los grupos populares.

Gráfico 1. Orígenes sociales de los canónigos doctorales. Siglos XVI y XVII

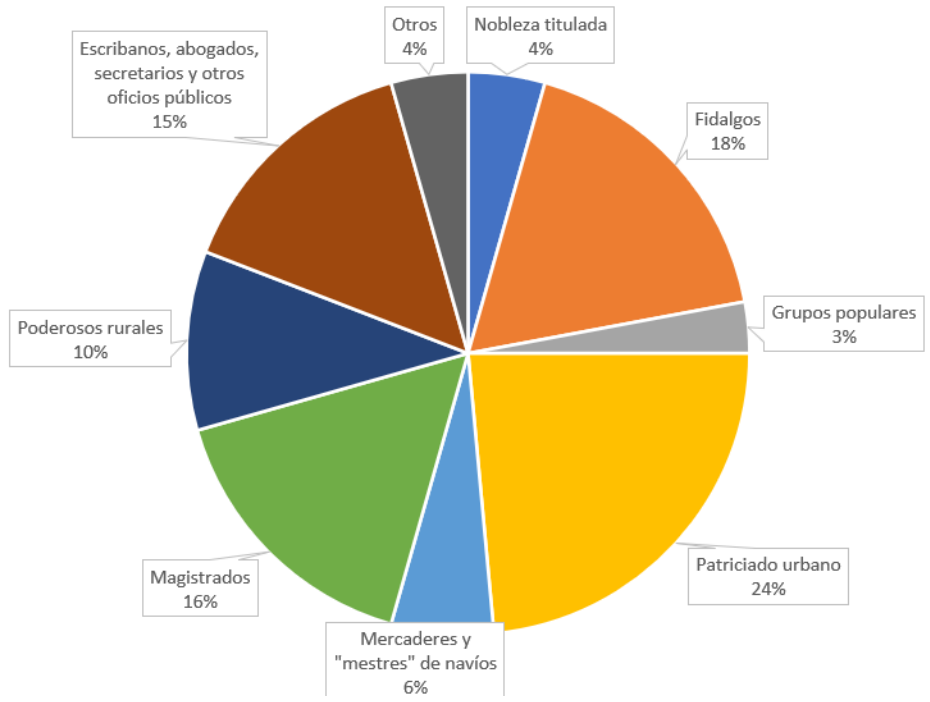

Fuentes: para los doctorales, véase el apartado correspondiente en el cuerpo del texto Nota: los porcentajes se han elaborado con relación al número de canónigos cuyos orígenes sociales conozco (68) y no al total de doctorales de los siglos XVI y XVII para evitar la distorsión que provocaría incluir un $16 \%$ con orígenes desconocidos, dado que la mayoría de éstos integraron los cabildos en el siglo XVI.

\section{La alta nobleza: de la fidalguia provincial a la alta nobleza de Corte}

Es muy complicado determinar cuántos canónigos doctorales procedían de familias de la alta nobleza del reino, si exceptuamos aquellos hijos o nietos de titulados. Ello se debe, en parte, a la propia evolución que experimentó este grupo entre mediados del siglo XVI y el último tercio del siglo XVII. Este proceso se caracterizó por tres elementos: la gradual reducción de los miembros de la alta nobleza, la restructuración del grupo de los titulados a raíz de los acontecimientos de 1640 y la progresiva identificación, tras la Restauración, de la élite aristocrática con la llamada "primera nobleza de corte". En este grupo se integraba la nobleza titulada, antes dispersa por las provincias, y algunas casas de gran relieve poseedoras de señoríos y mayoraz$\operatorname{gos}^{33}$.

La nobleza titulada - o sus segundones-sólo proporcionó tres canónigos doctorales durante los siglos XVI y XVII. No es poco: un 4,4\% de aquéllos cuyos orígenes conocemos y un $3,7 \%$ del total de doctorales, pues no parece probable que los de

33 Cunha, M. Soares da y Monteiro, N.: "Jerarquía nobiliaria y Corte en Portugal (siglo XV-1832)", en Chacón Jiménez, F. y Monteiro, N. (eds.): Poder y movilidad social. Cortesanos, religiosos y oligarcas en la Península Ibérica (siglos XV-XIX), Madrid, CSIC - Universidad de Murcia, 2006, p. 185. 
procedencia desconocida fuesen hijos de aristócratas. Se trata, en cualquier caso, de un porcentaje superior al de este grupo en el seno de la sociedad portuguesa. Antes de la Restauración, don Manuel Pereira y don Afonso de Faro obtuvieron las canonjías doctorales de Guarda y Oporto, respectivamente. El primero era nieto de los condes de Féria y el segundo hijo de los primeros condes de Vimiero, título creado por Felipe $\mathrm{III}^{34}$. Todo parece indicar que, tras la Restauración, estas prebendas poco podían ofrecer a los miembros de la aristocracia pues sus rentas eran, en general, inferiores a las de las dignidades de los cabildos. Probablemente no resultaban apetecibles para quienes podían acceder a ricos beneficios capitulares usando mecanismos que requerían menos esfuerzo personal que un concurso en la Universidad. Tras el fin de la guerra, el único doctoral perteneciente a la nobleza titulada fue Nuno da Silva Teles, hijo de los condes de Vila Maior, que ganó la de Braga en 1689.

Un grupo considerable de los canónigos doctorales procedía de familias fidalgas, una etiqueta en la que, no obstante, encontramos situaciones bastante diversas. De los miembros de la fidalguia, hubo dos doctorales hijos o nietos de señores y otro hijo de alcaides-mores. Recordemos que en Portugal los alcaides-mores tenían a su cargo alguna fortaleza tanto real como señorial, aunque en la Edad Moderna el oficio era ya meramente honorífico. Por su parte, como señaló Monteiro, el número de señoríos jurisdiccionales fue siempre muy reducido en Portugal y, tras la Restauración, se contrajo al mismo tiempo que la mayor parte de los señores alcanzaron un título nobiliario $^{35}$. De hecho, los tres canónigos originarios de familias de alcaides-mores y señores ingresaron en los cabildos antes de la Restauración. Se trataba de Diogo de Brito de Carvalho, doctoral de Coimbra, Lisboa y Évora, que era hijo y nieto de los alcaide-mores de Almeida; Simão Barreto de Meneses, doctoral de Viseu, nieto de los señores de Ponte da Barca, en la comarca de Viana ${ }^{36}$, y António da Silveira Freire, canónigo de Guarda, hijo del señor de Bobadela, Lagos da Beira, Covas y Travanca que también poseía el mayorazgo de Azinhal. A pesar del título, conviene tener presente que el señorío de Bobadela no era jurisdiccional y que el titular no tenía poder para dar o confirmar oficios. Simplemente recibía las rentas y derechos reales ${ }^{37}$.

Entre los doctorales del siglo XVI originarios de familias fidalgas podríamos incluir a Diogo Mendes de Vasconcelos y a António de Mendonça. El primero, canónigo de Évora en la segunda mitad del XVI, era hijo de un fidalgo de la casa del duque de Bragança, en una época en la que estas distinciones no se habían aún desvalorizado, y descendía de Mem Rodrigues de Vasconcelos, maestre de Santiago en tiempos de Juan ${ }^{38}$. El segundo, canónigo de Lisboa a finales del XVI, era hijo natural de Fernão de Mendonça, comendador de Serpa, y nieto de otro António de

34 Don Manuel Pereira era hijo natural de don João Pereira y nieto, por tanto, de don Manuel Pereira y doña Isabel de Castro, condes de Féria.

35 Monteiro, N.: "Nobleza y élites en el Portugal moderno en el contexto de la Península Ibérica (siglos XVII y XVIII)", en Soria Mesa, E. y otros (eds.): Las élites en la época moderna: la monarquía española, Córdoba, Universidad de Córdoba, 2009, vol. 1, p. 145.

36 Según Hespanha, Ponte da Barca fue donada a João de Magalhães em 1458 con rentas, jurisdicciones y presentación de los notarios y así fue confirmado por los monarcas sucesivos. Hespanha, A. M.: As vésperas do Leviathan. Instituçoes e poder politico. Portugal - sec. XVII, Rio de Mouro, ed. do autor, 1986, vol. 2, p. 23.

37 Ibidem, vol. 2, p. 384.

38 Morais, op. cit. (nota 16), I-2, pp. 128 y 138. La Casa de Bragança gozaba del privilegio de conferir nobleza, como el monarca. Sobre las distinciones concedidas por los duques de Bragança, vid. Cunha, M. Soares da: $A$ Casa de Bragança, 1560-1640. Práticas senhoriais e redes clientelares, Lisboa, Editorial Estampa, 2000, pp. 45-88. 
Mendonça, comendador de Veiros, Cano, Serpa y Moura. Sus bisabuelos paternos no podían ser más ilustres: Nuno Furtado de Mendonça, aposentador mayor del rey Alfonso V, y don Fernando de Almada, conde de Avranches ${ }^{39}$.

A lo largo del siglo XVII, se mantuvo la presencia fidalga en las canonjías doctorales. Dos familias de la alta nobleza provincial alentejana emparentadas entre sí, los Melo y los Barreto, proporcionaron tres canónigos doctorales a lo largo del Seiscientos, así como varios obispos, inquisidores y diputados del Consejo General. Francisco Barreto obtuvo la doctoral de Viseu en 1621 y su sobrino Martim Afonso de Melo, la de Faro en 1641. Un primo hermano de este último, Manuel de Moura Manuel, consiguió la doctoral de Lamego en 1660 y la de Braga en 1666. En Serpa, Moura y Vila Viçosa, sus familiares eran considerados "fidallgos de boa jerasão"40, "fidalgos ligitimos e conhecidos de solar"41, y "fidalgos muito honrados" taba de poderosas familias alentejanas que completaban su alta nobleza de sangre con honras y distinciones concedidas por la Corona, como las encomiendas de las Órdenes Militares y los fueros de fidalgo de la Casa Real ${ }^{43}$.

También había nacido en el seno de familias de la fidalguia provincial Miguel Soares Pereira, doctoral de Lamego y de Oporto en la primera mitad del XVII. Su padre y abuelo materno habían servido los oficios concejiles de Oporto, mientras que su abuelo paterno se negaba a servir los del concejo de Cambra porque consideraba que no entrañaban suficiente honra. Su familia parece ser un buen ejemplo de las poderosas casas fidalgas de Oporto. Sirva, como ejemplo, lo que decía un testigo sobre el abuelo materno del doctoral: "homem muito nobre he fidalgo principal desta cidade e que teve cavalos ginetes em sua estrebaria e escravos e criados com que se servio he teve os principaes carguos desta cidade e foi muito riquo os quais officios e cargos não servião senão os homẽs fidalgos" 44 .

El resto de los canónigos de origen fidalgo proceden ya de familias de Lisboa o de sus alrededores, como Setúbal. Se trata de Rui Fernandes de Saldanha, que obtuvo la doctoral de Faro en 1611; Rodrigo de Miranda Henriques, doctoral de Viseu entre 1657 y 1663, y João de Castilho, doctoral de Oporto desde 1660. Todos eran hijos de comendadores y en los casos de Miranda Henriques y Castilho, nietos también de comendadores. Además, padres, abuelos y hermanos gozaban de los fueros de fidalgos de la Casa Real ${ }^{45}$. Y todos lograron que su fidalguia fuera considerada ante-

39 Morais, op. cit. (nota 16), IV-1, pp. 446-448. Arquivo Nacional da Torre do Tombo (ANTT), Tribunal do Santo Ofício (TSO), Conselho Geral (CG), Habilitações, António, mç. 2, doc. 79.

40 ANTT, TSO, CG, Habilitações, Francisco, mç. 3, doc. 111, sin fol. (declaración de Sebastião Valente).

${ }^{41}$ ANTT, TSO, CG, Habilitações, Álvaro, mç. 3, doc. 45, fol. 12r.

42 ANTT, TSO, CG, Habilitações, Manuel, mç. 14, doc. 394, fol. 28v.

43 ANTT, TSO, CG, Habilitações, Francisco, mç. 3, doc. 111. ANTT, TSO, CG, Habilitações, Martim, mç. 1, doc. 16. ANTT, TSO, CG, Habilitações, Álvaro, mç. 3, doc. 45. ANTT, TSO, CG, Habilitações, Manuel, mç. 14, doc. 394. Morais, op. cit. (nota 16), I-1, pp. 543-546; IV-1, pp. 15-16 y p. 339; IV-2, pp. 76-81. Machado, op. cit. (nota 16), vol. 2, pp. 116-117; vol. 3, pp. 433-434. São Bento y Soares, op. cit. (nota 16), vol. 1, pp. 596597; vol. 2, p. 1428. Inventário dos Livros de Matrícula da Casa Real, vol. 2, pp. 5 y 283. Subtil, J. (coord.): Dicionário dos Desembargadores: 1640-1834, Lisboa, EDIUAL, 2010, pp. 183 y 467.

44 ANTT, TSO, CG, Habilitações, Miguel, mç. 1, doc. 6, sin fol. (declaración de Diogo Leitão de Carvalho). Machado, op. cit. (nota 16), vol. 3, p. 487. São Bento y Soares, op. cit. (nota 16), vol. 2, p. 1463.

45 ANTT, TSO, CG, Habilitações, Rui, mç. 1, doc. 7. ANTT, TSO, CG, Habilitações, Rodrigo, mç. 1 , doc. 7. ANTT, TSO, CG, Habilitações, António, mç. 6, doc. 277. ANTT, TSO, CG, Habilitações, João, mç. 8, doc. 278. ANTT, TSO, CG, Habilitações, Jerónimo, mç. 1, doc. 37. ANTT, TSO, CG, Habilitações, Pedro, mç. 3, doc. 97. ANTT, TSO, CG, Habilitações, Lopo, mç. 1, doc. 4. Inventário dos livros de Matrícula da Casa Real, vol. 2, pp. 278 y 343. Labrador Arroyo, F.: La Casa Real portuguesa de Felipe II y Felipe III: la articulación del reino a 
rior a la concesión de cualquier honra y dignidad, pues se estimaba que descendían de "fidalgos muj honrados e por taes tidos e avidos" "fidalgos muy conhecidos"48.

\section{El patriciado urbano}

Al menos un cuarto de los canónigos doctorales de los siglos XVI y XVII procedían de las élites urbanas. Se trata de un grupo muy diverso cuya definición resulta problemática, debido a las inevitables diferencias regionales y a la gran variedad de situaciones sociales y económicas, ya que en su seno podemos encontrar desde fidalgos hasta escribanos. Precisamente por este motivo, no hemos adoptado como criterio de clasificación el desempeño de los oficios concejiles de vereador (regidor) y juiz ordinário (alcalde ordinario), lo que habría resultado relativamente fácil. Si tal hiciéramos estaríamos asignando una identidad social a una categoría institucional, en palabras de Nuno Monteiro ${ }^{49}$. De hecho, en su estudio sobre los elegibles para desempeñar los oficios de vereadores, Monteiro demostró la diversidad de orígenes sociales de aquellos que integraban los gobiernos concejiles a finales del siglo $\mathrm{XVIII}^{50}$.

Otro problema radica en la propia evolución de los gobiernos municipales, que se fueron haciendo cada vez más elitistas a medida que avanzaba la Edad Moderna. Se trata de un proceso bien descrito por Romero Magalhães, cuyas ideas principales me limito a resumir aquí. Según Romero, durante el siglo XVI y principios del siglo XVII las gentes que ocupaban el gobierno de los concejos experimentaron un proceso de promoción social a medida que se reforzó el poder de los ayuntamientos. A partir de la década de 1570, comenzó a generalizarse en Portugal la expresión "gente nobre da governança", que fue sustituyendo a las anteriores denominaciones de ciudadanos y hombres buenos. Por su parte, a finales del siglo XVI, el término "ciudadano" pasó a significar noble y, con el tiempo, "ciudadano" y "noble" se usaron como sinónimos en la legislación. Por ello, ser ciudadano de algunos importantes concejos, como el de Oporto o el de Coimbra, constituyó un privilegio que podía ser concedido por los monarcas y que confería algo parecido a la nobleza ${ }^{51}$.

través de la integración de las élites de poder (1580-1621), Madrid, tesis doctoral defendida en la Universidad Autónoma de Madrid, 2006, vol. 2, pp. 702, 753, 843, 1047 y 1176.

46 ANTT, TSO, CG, Habilitações, Rui, mç. 1, doc. 7, fol. 14r.

47 ANTT, TSO, CG, Habilitações, António, mç. 6, doc. 277, fol. 7v.

48 ANTT, TSO, CG, Habilitações, Lopo, mç., 1, doc. 4, sin fol. (declaración de Fernão de Sousa).

49 Monteiro, N.: "Elites locais e mobilidade social em Portugal nos finais do Antigo Regime", en Idem: Elites e Poder. Entre o Antigo Regime e o Liberalismo, Lisboa, ICS, 2007, pp. 45.

50 Ibidem, p. 65.

51 Magalhães, op. cit. (nota 3), pp. 323-351; Magalhães, J. Romero: “A sociedade”, en Idem (coord.): No Alvorecer da Modernidade (1480-1620), Lisboa, Editorial Estampa, 1993, pp. 495-498; Magalhães, J. Romero: “As estruturas sociais de enquadramento da Economia Portuguesa de Antigo Regime: os concelhos", Notas Económicas, 4 (1994), p. 36. Sobre los ciudadanos de Coimbra y el privilegio de ciudadano concedido por el monarca, vid. Oliveira, A.: A vida econômica e social de Coimbra de 1537 a 1640, Coimbra, Palimage, 2016, vol. 1, pp. 407-409, nota 278. Sobre los ciudadanos de Oporto, sus privilegios y las vías de acceso al grupo, vid. Silva, F. Ribeiro da: O Porto e o seu termo (1580-1640): os homens, as instituições e o poder, Porto, Câmara Municipal do Porto, 1988, vol. 1, pp. 290-306. Sobre los vereadores de Évora durante la Unión Dinástica, Pardal, R.: As elites de Évora ao tempo da dominação filipina. Estratégias de controlo do poder local (1580-1640), Edições Colibri - CIDEHUS/UE, 2007. 
La Corona, a través de la legislación, reforzó el proceso de cierre de la élite municipal. En 1605, el rey determinó que sólo podrían ser elegidos para el oficio de vereador los hijos y nietos de ciudadanos. Se cerraba así una de las vías de movilidad social ascendente, que consistía en el desempeño del oficio de almotacén pues hasta principios del siglo XVII servir este cargo podía constituir una puerta de entrada en el grupo de los ciudadanos. De hecho, en 1611, el Desembargo do Paço, el más alto tribunal del reino, determinó que los almotacenes debían ser de una cualidad más baja que los vereadores, aunque, eso sí, debían vivir "à lei da nobreza". Finalmente, se cerró también el acceso al oficio de almotacén. En 1618, el rey estableció que quienes lo desempeñasen debían ser nobles, de los mejores de la tierra, y que no podían ser descendientes de oficiales mecánicos.

Teniendo en cuenta todo lo anterior, hemos integrado en el grupo de las élites urbanas a aquellos canónigos cuyos padres y abuelos se definían como ciudadanos, o eran considerados de los principales, de los más honrados, de los mejores y de los más ilustres, o al menos vivían "a ley de nobleza" en las ciudades. Incluimos aquí una gran variedad de familias de origen urbano a las que los contemporáneos consideraban "pessoas nobres e prinçipais" 52 ,"gente nobre e limpa" 53 , y "gente de comfiança, onrada e primcipal" ${ }^{4}$. Asimismo, englobamos en este grupo a los hijos y nietos de los integrantes de las cámaras municipales de las ciudades, de los proveedores de las Misericordias y de los capitanes mayores de las compañías de ordenanza, cargo este último que confería nobleza vitalicia a su titular ${ }^{55}$. No obstante, hemos decidido excluir de este grupo a aquellos cuyos padres, aunque desempeñasen oficios concejiles, contaban con signos de distinción más elevados en el contexto portugués del siglo XVII, como los títulos nobiliarios, los oficios mayores de la Casa Real, las encomiendas de las Órdenes Militares o los señoríos. Asimismo, tampoco hemos incluido a aquellos que eran considerados fidalgos de solar, al margen de que sirviesen de vereadores. Finalmente, hemos excluido también a quienes ejercieron los oficios municipales en pequeños concejos dado que, al considerar otros elementos, nos ha parecido más oportuno integrarlos en el grupo de los poderosos rurales.

Desde luego, las élites urbanas no son un grupo homogéneo. No obstante, los ciudadanos o la "gente noble del gobierno de las tierras" presentan algunas características comunes. Como señaló Romero Magalhães, en general tenían bienes raíces, aunque en algunos casos podían ser también grandes mercaderes. Para consolidar su situación, estas noblezas locales debían enviar a algunos de sus miembros a la Universidad de Coimbra y destinarlos al servicio regio en las instituciones que requerían grados en Derecho. En esta consolidación social "havia que meter a Igreja de través", en palabras del gran historiador portugués. Tal podía hacerse por medio del acceso a los beneficios capitulares, entre los que se encontraban las canonjías doctorales.

Como decimos, en algunas ocasiones, los padres y abuelos de los canónigos doctorales habían servido los oficios de alcalde ordinario (juiz ordinario) y regidor (vereador) o sus familias podían desempeñar los cargos concejiles. Así, la familia de Gaspar Pereira, doctoral de Braga, siempre sirvió los oficios del gobierno de las

ANTT, TSO, CG, Habilitações, Gaspar, mç. 1, doc. 18, sin fol. (declaración de João Gonçalves Serqueira). ANTT, TSO, CG, Habilitações, Lopo, mç. 1, doc. 2, sin fol. (declaración de Manuel Jorge de Seixas). ANTT, TSO, CG, Habilitações, Gregório, mç. 1, doc. 4, fol. 4r.

55 Las compañías de ordenanza, reorganizadas por don Sebastián en 1570, eran las milicias locales, con oficiales de carácter honorífico y, en realidad, muy poco efectivas desde el punto de vista militar. 
villas de Mondim y Ponte de Lima, de donde era el canónigo. Ciudadanos del poderoso municipio de Oporto fueron los padres de Manuel Seabra, Miguel Soares Pereira -a quien hemos incluido en el grupo de los fidalgos-, y Gonçalo Alvo Godinho, así como el abuelo de Francisco Carneiro de Figueirôa ${ }^{56}$. Por su parte, los padres de Manuel Machado de Andrade y Manuel Pinheiro Sotomaior fueron vereadores de Viseu. El padre de Manuel Machado de Andrade pertenecía, además, a uno de los dos bandos en los que se dividía la nobleza urbana ${ }^{57}$. Asimismo, sirvió como vereador y juez ordinario en Lamego el padre de Marcos Teixeira, canónigo doctoral de Évora a principios del siglo XVII ${ }^{58}$. En tierras de Estremadura, el padre de António de Gouveia e Sousa, considerado noble y de mucha calidad, ejerció de vereador de Leiria $^{59}$. Finalmente, también fue verador y juez ordinario, en este caso de Montemor-o-Velho, el padre de Manuel da Gama Lobo, canónigo de Braga y Évora en el tránsito del XVII al XVIII. Además, desempeñó el cargo de procurador en Cortes de Montemor-o-Velho y fue familiar del Santo Oficio, proveedor de la Misericordia, capitán de infantería y caballero de la Orden de Avis ${ }^{60}$.

Con alguna frecuencia, estas gentes principales de las ciudades eran propietarias de oficios de escribanos, lo que no quiere decir que los sirvieran personalmente. Entre estos oficios se encontraban los de escribanos de la cámara (escrivão da cámara), notarios públicos y judiciales (tabelião das notas y tabelião do judicial), escribano de las sisas (escrivão das sisas), escribano del corregimiento (escrivão da correição) y escribano de los huérfanos (escrivão dos órfãos). Según Roberta Stumpf, aunque estos oficios eran remunerados, no resultaban incompatibles con la nobleza. Además, en el siglo XVII muchos de estos oficios fueron concedidos en propiedad por la Corona. Los propietarios, por su parte, tenían el derecho de arrendar el oficio, renunciar a él o venderlo ${ }^{61}$. Por eso, en algunos casos, da la sensación de que los padres de los doctorales no los servían personalmente. El padre y el abuelo del canónigo Marcos Teixeira, considerados principales, nobles y ciudadanos, tuvieron oficios de escribanos: el padre el de escribano de las comarcas de Lamego y Viseu, y el abuelo el de escribano de los huérfanos, cámara y sisas de Mondim $^{62}$. El padre del doctor António de Gouveia e Sousa, considerado noble y de mucha calidad, también fue propietario

56 A finales del siglo XVIII, el ayuntamiento de Oporto era el más aristocrático de todo el país. Para entonces, según Nuno Monteiro, había desaparecido ya la designación de "ciudadano" de Oporto, que aún aparecía con frecuencia en el siglo XVII. En el siglo XVII, ya se trataba de un ayuntamiento muy aristocrático y la mayoría de sus vereadores gozaban del fuero de fidalgo de la Casa Real, según Francisco Ribeiro da Silva. Monteiro, op. cit. (nota 49), p. 60; Silva, op. cit. (nota 51), pp. 428-433. Sobre los vereadores de Oporto del siglo XVI, vid. Brito, P. de: Patriciado urbano quinhentista: as famílias dominantes do Porto (1500-1580), Porto, Câmara Municipal do Porto, 1997.

57 ANTT, TSO, CG, Habilitações, Manuel, mç. 15, doc. 396. ANTT, TSO, CG, Habilitações, Manuel, mç. 7, doc. 222.

58 ANTT, TSO, CG, Habilitações, Marcos, mç. 1, doc. 7.

59 Machado, op. cit. (nota 16), vol. 4. pp. 37-38. ANTT, Cabido da Sé de Lamego (CSLM), Habilitações, mç. 4, n. 155. ANTT, TSO, CG, Habilitações, Francisco, mç. 9, doc. 332. ANTT, TSO, CG, Habilitações, António, mç. 12, doc. 470.

60 ANTT, TSO, CG, Habilitações, Manuel, mç. 10, doc. 287. ANTT, TSO, CG, Habilitações, Manuel, mç. 34, doc. 743. ANTT, TSO, CG, Habilitações, Manuel, mç. 50, doc. 1097. Machado, op. cit. (nota 16), vol. 3, pp. $273-$ 274. São Bento y Soares, op. cit. (nota 16), vol. 2, p. 1350. Subtil, op. cit. (nota 43), p. 435.

${ }_{61}$ Stumpf, R.: "Os provimentos de ofícios: a questão da propriedade no Antigo Regime português", Topoi, vol. 15, n. 29 (2014), p. 619.

62 ANTT, TSO, CG, Habilitações, Marcos, mç. 1, doc. 7. ANTT, CHR, D. Sebastião e D. Henrique, Doações, liv. 14 , fol. $103 \mathrm{v}-104 \mathrm{r}$. 
de un oficio, en este caso el de "escrivão do campo e vallas" de Leiria, dado por los marqueses de Vila Real ${ }^{63}$. También los canónigos António de Almedia de Castelo Branco y Manuel Machado de Andrade, su sobrino, pertenecían a una familia noble y principal de los concejos de Besteiros y Viseu. En esta última ciudad, Sebastião de Alvelos, padre del primero y abuelo del segundo, tuvo en propiedad el oficio de escribano del corregimiento de Viseu ${ }^{64}$.

En alguna ocasión, los ciudadanos principales entroncaban con familias de comendadores de Órdenes Militares. En Portugal, sobre todo a raíz de la Restauración, las encomiendas fueron quedando progresivamente en manos de la alta nobleza de Corte. Por ello, a partir de mediados del XVII cada vez resulta más raro encontrar comendadores fuera de Lisboa que desempeñasen el oficio de vereador ${ }^{65}$. No obstante, antes de la Restauración, sí encontramos algún que otro comendador que entroncó con familias de un estatuto nobiliario algo inferior. Así ocurrió en la familia de Gaspar Pereira, doctoral de Braga entre 1607 y 1636. Sus abuelos paternos eran principales de Monção, en la comarca de Viana do Castelo, mientras que su abuelo materno, natural de Ponte de Lima, era comendador de Troviscoso de la Orden de Cristo. A pesar de que se trataba de una encomienda bastante modesta, proporcionaba a su propietario en torno a 120.000 réis anuales a principios del XVII y un título, el de comendador, nada despreciable y mucho menos en el contexto local ${ }^{66}$.

\section{EI poder de las élites de letrados}

El segundo grupo que proporcionó más canónigos doctorales a la Iglesia portuguesa durante los siglos XVI y XVII fue el de los letrados. Al menos catorce eran hijos de personas con formación en Derecho, bien en la Universidad de Coimbra bien en el extranjero. De ellos, al menos once desempeñaron los oficios más elevados en la administración de justicia: desembargadores, ouvidores y juizes de fora. A ellos nos referimos en este apartado sobre las élites letradas.

En Portugal, los miembros de los altos tribunales de justicia, tanto regios como señoriales, se llamaban desembargadores, término que no podemos traducir por el de oidores para evitar la confusión terminológica. Los ouvidores eran los jueces nombrados por los señores para el ejercicio de la justicia en las tierras de su jurisdicción $^{67}$. En Castilla se llamaban alcaldes mayores pero hemos preferido mantener

63 ANTT, CSLM, Habilitações, mç. 4, n. 155. ANTT, TSO, CG, Habilitações, Francisco, mç. 9, doc. 332. ANTT, TSO, CG, Habilitações, António, mç. 12, doc. 470. Machado, op. cit. (nota 16), vol. 4. pp. 37-38.

64 En 1608, Felipe III concedió a Sebastião de Alvelos que pudiese renunciar en uno de sus hijos el oficio de escribano del corregimiento de Viseu. ANTT, CHR, D. Filipe II, Doações, liv. 26, fol. 36. ANTT, TSO, CG, Habilitações, Manuel, mç. 15, doc. 396. ANTT, TSO, CG, Habilitações, Manuel, mç. 7, doc. 222.

65 Monteiro, N.: "Poderes e circulação das elites em Portugal: 1640-1820", en Idem: Elites e Poder. Entre o Antigo Regime e o Liberalismo, Lisboa, ICS, 2007, pp. 111 y 135. De hecho, a finales del siglo XVIII, sólo se encuentran comendadores o señores de tierras elegibles para desempeñar el oficio de vereador en los concejos de Oporto, Torre de Moncorvo, Santarem y Funchal: Monteiro, op. cit. (nota 49), pp. 59 y 64.

66 ANTT, TSO, CG, Habilitações, Gaspar, mç. 1, doc. 18. Morais, op. cit. (nota 16), I-1, pp. 124-125 y 141-142. São Bento y Soares, op. cit. (nota 16), vol. 1, p. 732. Costa, op. cit. (nota 16), tomo 1, p. 212. Los datos de la evaluación de la encomienda de Troviscoso a principios del XVII proceden de Falcão, L. de Figueiredo: Livro em que se contém toda a fazenda e real património dos reinos de Portugal, Índia e Ilhas adjacentes, Lisboa, Imprensa Nacional, 1859, pp. 217-218.

67 En Portugal, la jurisdicción señorial era de segunda instancia. Los ouvidores conocían de los recursos de las sentencias dictadas por los jueces ordinarios. Hespanha, op. cit. (nota 28), p. 397. Sobre los desembargadores 
el término portugués de ouvidores para evitar malentendidos, ya que en Portugal los alcaides-mores eran, como dijimos, quienes tenían a su cargo alguna fortaleza ${ }^{68}$. También hemos decidido conservar en portugués el término juiz de fora. Estos magistrados podrían equivaler a los alcaldes mayores castellanos, de nombramiento real en villas de realengo, pero la utilización de este término puede inducir a error, como hemos señalado.

La mayoría de los magistrados padres de doctorales llegaron a desempeñar el oficio de desembargador en uno de los dos altos tribunales de justicia del reino: la Relação do Porto y la Casa da Suplicação. Ello pone de manifiesto que nuestros canónigos procedían de familias con conexiones con la Universidad de Coimbra y con la Corte real y, por lo tanto, bien enteradas de los entresijos de la organización y funcionamiento burocrático del país. En este grupo podemos incluir a Bento de Beja de Noronha, doctoral de Guarda; Francisco Cardoso de Torneo, de Lamego; Francisco Mendes Pimentel, de Coimbra; Francisco Rodrigues Cação, de Lamego; Gonçalo Mendes de Vasconcelos, de Évora; Luís Pereira de Castro, de Braga y Coimbra, y Luís Ribeiro de Leiva, de Coimbra y Lisboa. Junto a ellos, se incluyen en este grupo a dos hijos de desembargadores de la Casa de Bragança en el tribunal que los duques tenían en Vila Viçosa: los doctores Jaime de Morais, canónigo de Coimbra, y Tomé Peixoto de Sá, prebendado en Lamego y Coimbra. Finalmente, hubo otros dos canónigos cuyos padres no llegaron a alcanzar la cima de la carrera letrada: el padre del doctor Pantaelão Rodrigues Pacheco, canónigo de Coimbra y de Lisboa, desempeñó el oficio de juiz de fora de Loulé (Algarve), y el de João de Soveral Machado, doctoral de Faro y Coimbra, fue ouvidor de Mortágua, villa de los condes de Odemira ${ }^{69}$.

Buena parte de los letrados padres de los doctorales lo fueron, asimismo, de otros magistrados la mayoría de los cuales llegaron a desempeñar el oficio de desembargador. El canónigo Bartolomeu da Fonseca fue hermano del desembargador Lançarote Leitão; Francisco Mendes Pimentel, del desembargador Luís Coelho Pimentel; Gonçalo Mendes de Vasconcelos, del desembargador Jorge de Cabedo; João de Sobral Machado, del juiz de fora Henrique de Abreu Machado; Luís Pereira de Castro, del desembargador Gabriel Pereira de Castro, y Tomé Peixoto de Sá, del ouvidor Manuel Peixoto. Como decimos, todos ellos eran hijos de letrados.

No obstante, no conviene exagerar el peso de las dinastías letradas, y mucho menos a partir de este grupo de análisis tan reducido como es el de los familiares de los canónigos doctorales. Como demostró Nuno Camarinhas, el porcentaje de magistrados portugueses que descendían de otros jueces o, incluso, de personas formadas en Derecho era relativamente reducido. Según sus datos, entre 1620 y 1800, sólo el 13\% de los magistrados de la Corona eran hijos de juristas ${ }^{70}$.

Los datos proporcionados por Camarinhas explicarían el escaso porcentaje de canónigos doctorales que, a pesar de ser hijos de letrados, descendían de abuelos for-

de la Casa de Bragança, en el tribunal ducal de Vila Viçosa, y los ouvidores, vid. Cunha, op. cit. (nota 38), pp. 222-229 y 273-277.

68 En Castilla, a veces los señores llamaban a sus jueces gobernadores o corregidores, por el deseo de asimilarlos a los de la Corona.

${ }^{69}$ Asimismo, es posible que el padre de Jerónimo Teixeira Cabral fuese el doctor Francisco Teixeira, juiz de fora de Monção. ANTT, TSO, CG, Habilitações, Pantaleão, mç. 1, doc. 3. ANTT, CHR, D. Filipe I, Doações, liv. 27, fol. 298v. ANTT, TSO, CG, Habilitações, João, mç. 17, doc. 446. ANTT, TSO, CG, Habilitações, Henrique, mç. 4, doc. 62. ANTT, CHR, D. Sebastião e D. Henrique, Doações, liv. 19, fol. 75r.

70 Camarinhas, op. cit. (nota 30), p. 150. 
mados en Leyes. De hecho, sólo podría decirse que Bento de Beja de Noronha, que obtuvo la doctoral de Guarda en 1661, y Luís Pereira de Castro, que ganó las de Braga y Coimbra en 1636 y 1637, pertenecían a verdaderas dinastías de letrados. Así, el abuelo materno de Beja de Noronha había sido proveedor en Lamego y corregidor en Tomar, mientras que su abuelo paterno desempeñó el oficio de desembargador de la Casa da Suplicação ${ }^{71}$. Por su parte, el abuelo materno de Luís Pereira de Castro, tras servir como desembargador en el tribunal eclesiástico de Braga, llegó a la Casa da Suplicação, y el padre del canónigo sirvió en la Relação do Porto ${ }^{72}$. Además, como hemos dicho, ambos canónigos doctorales fueron hermanos de desembargadores.

\section{La hora de los poderosos rurales}

En la segunda mitad del siglo XVII, un grupo social empieza a cobrar fuerza en las canonjías doctorales: el de los labradores ricos o hacendados. En él podríamos incluir a nueve canónigos, la mayoría de los cuales accedieron a sus prebendas en la segunda mitad del Seiscientos. Sus padres y abuelos eran labradores con cierta solvencia económica o directamente ricos. Labraban sus propias tierras u otras que tenían arrendadas, no directamente sino a través de criados, tomaban en arriendo rentas tanto eclesiásticas como seculares, quizá poseían ganado, contaban con bestias de labor y de tiro, y en sus casas se servían de criados y esclavos. En algunos casos, se enorgullecían de vivir "à lei da nobreza", expresión que refleja su buen pasar económico, su ausencia de trabajo manual y la posesión de criados, esclavos domésticos y, sobre todo, caballos en los establos. A veces desempeñaban cargos concejiles y en las compañías de ordenanzas, como el de alférez y capitán. Se definían como labradores ricos, principales, honrados y limpios, más en un sentido socioeconómico que racial. Como señaló José Vicente Serrão, la clasificación de "labrador" implicaba un estatus que presuponía cierta notoriedad en el contexto local y una posición superior entre aquellos vinculados a las actividades agrícolas ${ }^{73}$.

En el siglo XVI, sólo hubo un canónigo doctoral hijo de hacendados rurales. Se trató de Domingos Riscado, nacido en torno a 1544 en el lugar de Carregal de la villa de Currelos (comarca de Viseu). Sus padres eran "pessoas homradas e riquas" y sus abuelos maternos "pessoas honradas dos principaes do dito llugar lavradores ricos e abastados". Los testigos de su prueba de limpieza de sangre definieron a estas gentes como "pessoas nobres dos principaes da terra, lavradores honrrados e abastados", una aparente contradicción en el contexto castellano -labrador noble- que no lo es en el portugués de la época. Como explicó Romero Magalhães, noble hacía referencia a ese grupo indefinido entre los plebeyos y los fidalgos, a aquellos que se comportaban de un modo honroso y, por ello, ocupaban los cargos reservados a los principales. Así ocurría con el padre del canónigo, que sirvió como alcalde ordinario (juiz ordinário) y regidor (vereador) de la villa de Currelos ${ }^{74}$.

71 ANTT, TSO, CG, Habilitações, Bento, mç. 1, doc. 21. Morais, op. cit. (nota 16), II-1, pp. 473-474. São Bento y Soares, op. cit. (nota 16), vol. 1, pp. 115 y 282, y vol. 2, p. 1225.

72 ANTT, TSO, CG, Habilitações, Luís, mç. 1, doc. 18. Morais, op. cit. (nota 16), I-1, pp. 363-364. Machado, op. cit. (nota 16), vol. 3, pp. 126-127. São Bento y Soares, op. cit. (nota 16), vol. 1, p. 163 y p. 606 y vol. 2, p. 1286. Subtil, op. cit. (nota 43), p. 412.

73 Serrão, J. V.: "Lavradores", en Madureira, N. L. (coord.): História do trabalho e das ocupações, vol. III, Oeiras, Celta Editora, 2002, p. 76.

74 Magalhães, op. cit. (nota 51, 1993), p. 490. ANTT, TSO, CG, Habilitações, Domingos, mç. 1, doc. 21 , sin fol. 
El momento de triunfo de los hacendados rurales en lo que atañe al acceso a las canonjías doctorales fue, como hemos dicho, la segunda mitad del siglo XVII. A partir de la década de 1660 pasaron a ocupar las doctorales, transitando a veces de unas a otras, André Bernardes Aires, Manuel da Costa de Almedia, Roque Ribeiro de Abreu, João Rodrigues Pinto, António Teixeira Álvares, António de Matos Bernardes, todos vástagos de poderosos rurales. El grupo se amplía si incluimos en él a los hermanos Félix y Pedro Ribeiro do Lago, a Francisco Mendes Pimentel y a João de Sobral Machado. Sus abuelos eran labradores honrados y principales, pero a sus padres ya debemos integrarlos en otras categorías socioeconómicas.

Todos estos canónigos procedían de zonas rurales y de familias con cierto poder económico y prestigio social, al menos en el ámbito local. Las situaciones se repiten en las regiones de Minho, Beira y Estremadura. En el couto del monasterio de Renfude, al norte de Braga, los abuelos de los doctores Ribeiro do Lago, eran considerados "lavradores honrados dos principaes do couto de Rendufe" 75 . En São Romão do Corgo, parroquia rural de Celorico de Basto, los abuelos del doctor António Teixeira Álvares eran "lavradores honrrados que viviam de sua fazenda muito limpa e abastadamente" "76. Mucho más al sur, en el lugar de Santo Varão, término de Montemor-o-Velho, el abuelo del doctor Francisco Mendes Pimentel tenía "grande nomem" y vivía de "mandar lavra (sic) terras no monte e no campo para o que tinha seus criados"77. En el lugar de Figueiró do Campo, también del amplio término rural de Montemor-o-Velho, los padres del doctor André Bernardes Aires "não tiveram algum oficio mecanico e viveram todos a ley da nobreza por serem dos principais da terra servindo-se com criados e criadas e bestas de sella e carne de cassa"78. Vida semejante debía llevar el padre del doctor António de Matos Bernardes, en el lugar de Turcifal, término de Torres Vedras. En 1674, sus convecinos señalaban que era muy rico, lo que veinticinco años más tarde se transformó en vivir "à lei da nobreza"

Los hacendados rurales con iniciativa económica a veces llevaban a cabo actividades financieras de ámbito regional. Así lo hizo el padre del doctor João Rodrigues Pinto, que fue arrendatario de las rentas que el poderoso monasterio de Santa Cruz de Coimbra percibía en la jurisdicción (couto) de Maiorca, lindante con Montemor-o-Velho ${ }^{80}$. También el padre del doctor Manuel da Costa de Almeida negociaba con rentas además de poseer hacienda propia. Morador en la parroquia de São Miguel de Arcos, término de Barcelos, y en Vila do Conde, negociaba con los

(declaraciones de Domingos Afonso, Simão João y João Anes; la cursiva es nuestra).

75 Los coutos eran tierras exentas de la jurisdicción ordinaria. Hespanha, op. cit. (nota 28), p. 105. ANTT, TSO, CG, Habilitações, Manuel, mç. 1, doc. 14, fol. 5v.

76 ANTT, TSO, CG, Habilitações, António, mç. 28, doc. 756, fol. 18v.

77 Los duques de Aveiro ejercían la jurisdicción criminal en el couto de Santo Varão por medio de su oidor de Montemor-o-Velho. Sin embargo, el obispo de Coimbra ejercía la jurisdicción civil. Promptuario das terras de Portugal, 1689, p. 192, Biblioteca do Exército, 1246/B. ANTT, TSO, CG, Habilitações, Francisco, mç. 26, doc. 664, fol. 28v. ANTT, TSO, CG, Habilitações, Luís, mç. 5, doc. 137, fol. 10v.

78 ANTT, TSO, CG, Habilitações, André, mç. 2, doc. 53.

79 En 1675, Domingos Bernardes fue nombrado familiar del Santo Oficio. En ese momento, los testigos señalaron insistentemente que era muy rico. En 1701, cuando su hijo ingresó en el Santo Oficio, los testigos de su prueba de limpieza usaron de manera recurrente la expresión “à lei da nobreza” para referirse al modo de vida del padre. ANTT, TSO, CG, Habilitações, Domingos, mç. 6, doc. 168. ANTT, TSO, CG, Habilitações, António, mç. 40, doc. 947.

80 Según Hespanha, la Universidad de Coimbra poseía la jurisdicción civil del couto de Maiorca. Hespanha, op. cit. (nota 36), vol. 2, p. 80. ANTT, TSO, CG, Habilitações, João, mç. 27, doc. 656, fol. 34r. 
diezmos de la parroquia de São Julião de Passos, también del término de Barcelos ${ }^{81}$. Y, por lo que parece, el padre del doctor Roque Ribeiro de Abreu, además de vivir de su hacienda, trataba a veces con rentas en el concejo de Midões ${ }^{82}$. Lo mismo hacía el abuelo paterno del doctor João de Sobral Machado que, aparte de otras rentas, cobraba las de Mortágua, villa de los condes de Odemira; además, era tesorero de la bula de la Cruzada ${ }^{83}$.

Los poderosos rurales, padres y abuelos de nuestros canónigos doctorales, intentaron consolidar su posición social por medio del desempeño de cargos y oficios que conferían honra más allá del ámbito local. Para ello servía, por ejemplo, el oficio de familiar del Santo Oficio, que certificaba, al menos sobre el papel, la limpieza de sangre de la familia. O los cargos de capitán y alférez de las compañías de ordenanza, que conferían nobleza. Familiares del Santo Oficio fueron el padre del canónigo António de Matos Bernardes y un hermano del doctoral Roque Ribeiro de Abreu ${ }^{84}$. Por su parte, el padre y el abuelo materno del doctor João Rodrigues Pinto, moradores en el lugar de Abrunheira, término de Montemor-o-Velho, fueron capitanes de la ordenanza y el ya citado progenitor de António de Matos Bernardes desempeñó el oficio de alférez. Y, en lo que parece un claro proceso de ascensión social, el hermano del doctor António Teixeira Álvares, que vivía "muito limpa e abastadamente de grandes fazendas que tem", alcanzó las distinciones de fidalgo de la Casa Real y capitão-mor de Celorico de Basto ${ }^{85}$.

Finalmente, tengamos presente que estos poderosos rurales a quienes nos estamos refiriendo entroncaron y se mezclaron con otros grupos de las élites portuguesas, como los letrados o las oligarquías urbanas. Así, aunque sus abuelos paternos habían sido labradores honrados, el padre de los doctores Ribeiro do Lago acabó integrándose en las élites concejiles de la ciudad de Braga ${ }^{86}$. Por su parte, los doctores Mendes Pimentel y Sobral Machado, ambos nietos de labradores, eran ya hijos de letrados que habían estudiado en la Universidad de Coimbra y sus hermanos desempeñarían cargos en la magistratura regia ${ }^{87}$.

81 Un labrador de la parroquia de São Julião de Passos afirmaba que había estado mucho tempo al servicio de Gaspar Gonçalves, padre del canónigo doctoral, "acaretandolhe pão e vinho pera a caza da renda que trazia desta abbadia [parroquia]”. ANTT, TSO, CG, Habilitações, Manuel, mç. 19, doc. 484, sin fol. (declaración de Nicolau Francisco).

82 ANTT, TSO, CG, Habilitações, Nicolau, mç. 1, doc. 19, sin fol. (declaración de Marcos de Lemos). Midões pertenecía a la comarca de Guarda.

83 ANTT, TSO, CG, Habilitações, Henrique, mç. 4, doc. 62.

84 Nicolau Ribeiro de Abreu, hermano del doctoral Roque Ribeiro de Abreu, fue nombrado familiar del Santo Oficio em 1683. Sus padres y abuelos paternos habían vivido de sus haciendas pero él ya era considerado, en el momento de su prueba de limpieza de sangre, "homem nobre que vivía de suas fazendas". ANTT, TSO, CG, Habilitações, Nicolau, mç. 1, doc. 19, sin fol. (declaración de Marcos de Lemos).

85 ANTT, TSO, CG, Habilitações, Bento, mç. 4, doc. 74, fol. $18 \mathrm{r}$.

86 ANTT, TSO, CG, Habilitações, Félix, mç. 1, doc. 1, sin fol. (declaración de Luís de Mota de Novais).

87 Luís Coelho Pimentel, hermano del canónigo Francisco Mendes Pimentel, sería oidor en la villa de Tentúgal y, más tarde, desembargador de la Relação do Porto. Por su parte Henrique de Abreu Machado, hermano del doctoral João de Soberal Machado, sería juez de fuera en Aveiro y Miranda. Ambos ingresaron como familiares en el Santo Oficio y eran considerados de los principales de sus respectivos lugares. São Bento y Soares, op. cit. (nota 16), vol. 1, p. 662. ANTT, TSO, CG, Habilitações, Luís, mç. 5, doc. 137. ANTT, TSO, CG, Habilitações, Francisco, mç. 26, doc. 664. ANTT, TSO, CG, Habilitações, João, mç. 17, doc. 446. ANTT, TSO, CG, Habilitações, Henrique, mç. 4, doc. 62. 


\section{Otros grupos intermedios}

Un 20\% de los canónigos cuyos orígenes conocemos procedía de estratos sociales intermedios, situados por debajo de los principales y poderosos, pero por encima de los grupos populares. Una vez más, nos encontramos con una gran diversidad de situaciones, porque hemos de tener en cuenta que estas posiciones intermedias lo son en relación con el contexto local y éste varía enormemente. Entre estos canónigos encontramos a hijos de escribanos que no incluimos en la categoría de las élites urbanas, bien porque desempeñasen dichos oficios en pequeñas poblaciones, bien porque lo hiciesen en la ciudad de Lisboa. Asimismo, en este grupo intermedio podemos integrar a algún hijo de secretarios, de abogados y de aquellos que servían cargos que podríamos considerar de la administración periférica, como el de almojarife o el de asistente del correo mayor del reino.

Por otra parte, dentro de los grupos intermedios podemos incluir también a tres canónigos -dos de ellos hermanos- hijos de mercaderes, todos de la segunda mitad del XVII. Ninguno de ellos formaba parte de la élite mercantil portuguesa constituida, en buena medida, por los grandes mercaderes conversos. Además, ninguno procedía del mundo del comercio y lo abandonó tan pronto como pudo. El paso por el comercio constituye una fase transitoria en procesos de ascenso social que llevan a estas gentes a integrarse finalmente en las élites urbanas.

Dionísio Rebelo de Gondim parece haber sido un auténtico experto en la obtención de prebendas doctorales, pues pasó por las de Viseu, Lamego, Guarda y Braga en el período comprendido entre 1655 y 1660 . Nieto de un zapatero y un sastre, su padre llevó a cabo un proceso de ascenso social basado en el enriquecimiento. Gonçalo Álvares Gondim, padre del canónigo, abandonó el oficio de zapatero y se dedicó a comerciar al por mayor con el extranjero. Como hemos señalado anteriormente, a principios del siglo XVII, el oficio de almotacén podía constituir una puerta de entrada en las oligarquías municipales y de él se sirvió para ir adquiriendo un estatuto noble en Viana do Castelo. Su ascenso se vio coronado cuando uno de sus hijos consiguió el fuero de fidalgo de la Casa Real y el otro, el doctoral, el oficio de desembargador de la Casa da Suplicação. No obstante, ninguno de los dos logró borrar los rumores sobre la limpieza de sangre de su familia que surgían periódicamente y que impidieron al canónigo ingresar en el Santo Oficio ${ }^{88}$.

Mucho más éxito tuvo Manuel Ribeiro do Lago, padre de los canónigos Félix y Pedro Ribeiro do Lago, debido probablemente a su mejor punto de partida. Sus padres eran labradores honrados y principales de São Martinho do Lago y él se dedicó durante un tiempo al comercio de paños. Más tarde, pasó a ser considerado ciudadano de Braga y desempeñó cargos en el gobierno concejil. Tanto él como sus hijos lograron ingresar en el Santo Oficio, lo que les proporcionó el certificado oficial de una limpieza que nunca parece haber sido cuestionada.

Finalmente, dentro de los grupos sociales intermedios habría que incluir también a Valério Farinha, doctoral de Guarda y Oporto a finales del XVII. Su padre y abuelo paterno eran mestres y capitanes de sus propios navíos en Leça de Matosinhos, puerto de mar anexo al de Oporto. En realidad, bajo la denominación común de "mestre de navios" podían incluirse diversas realidades económicas a veces

88 ANTT, TSO, CG, Habilitações, Dionísio, mç. 1, doc. 6. Morais, op. cit. (nota 16), V-2, pp. 277-278. São Bento y Soares, op. cit. (nota 16), vol. 1, p. 479. Subtil, op. cit. (nota 43), p. 154. 
bastante prósperas como se ve en Oporto ${ }^{89}$. En el caso que nos ocupa, el hecho de ser propietarios de sus propios barcos refleja una buena situación económica que sitúa a los padres y abuelos del futuro canónigo por encima de la demás "gente de mar" de la villa ${ }^{90}$.

\section{Los grupos populares}

Las canonjías doctorales portuguesas no parecen haber constituido un medio preferente de ascenso social de aquellos cuyos padres desempeñaban oficios mecánicos. Este tipo de prebendas quedaba muy lejos de las posibilidades de muchos artesanos, pues suponía años de estudio en la Universidad de Coimbra, que había que costear, y otros posteriores dedicados a las oposiciones a los colegios mayores, las cátedras universitarias y las propias canonjías. Quizá por ello, da la sensación de que incluso los canónigos doctorales de origen más popular proceden de familias con alguna capacidad económica. Tal parece ser el caso de João Duarte Ribeiro, canónigo de Lamego y de Évora en el tránsito del siglo XVII al XVIII. En Lisboa, su padre y abuelo paterno ejercían el oficio de volanteiros, mientras que su abuelo materno había sido guadamecilero. La familia debía gozar de algún bienestar económico, pues el abuelo paterno poseía unas casas que arrendaba y el padre era escribano de las décimas de la parroquia de San Nicolás y tesorero de la Misericordia de Lisboa ${ }^{91}$. Además, estaban bien relacionados: su abuelo materno y su padre fueron familiares del Santo Oficio y el hermano de su madre desempeñó el oficio de solicitador del tribunal.

Quizá el caso más exitoso de entre los doctorales sea el de Pedro Álvares Garrido, natural de Castelo da Vide, en la comarca de Portalegre, hijo y nieto de arrieros y hermano de un herrador que a veces se debía dedicar también al mercadeo. No obstante, no olvidemos que ello, en ningún caso, quiere decir que se tratase de personas pobres o con pocos recursos económicos. Estamos hablando de una profesión, no de un nivel de vida. Sea como fuere, pocos hijos de arrieros alcanzarían en el siglo XVII el éxito de Álvares Garrido en las carreras docente y eclesiástica. Doctor en Cánones, logró ingresar en el colegio de San Pablo e ir ascendiendo los escalones de la carrera docente hasta alcanzar la cátedra de Vísperas de Cánones. Al mismo tiempo, se especializó en los concursos para obtener prebendas doctorales y fue el único canónigo de la Edad Moderna que logró cinco de ellas. Además, para poder percibir los frutos de sus prebendas sin residir en ellas -aunque afirmase que tal no era su objetivo- consiguió ingresar en el Santo Oficio, como diputado de Coimbra. Le faltó ascender a los altos tribunales del reino pero, a su muerte en

89 Entre las personas que declararon mayor volumen de mercancías en la alfândega de Oporto entre 1580 y 1640 , se encontraban seis "mestres de navios". El valor de sus mercancías oscilaba entre los 322.020 y los 3.362.900 réis. Silva, op. cit. (nota 51), pp. 126-130.

90 ANTT, TSO, CG, Habilitações, Valério, mç. 1, doc. 4. Cf. POLÓNIA, A.: "Mestres e pilotos das carreiras ultramarinas (1596-1648)", Revista da Faculdade de Letras - História, II série, vol. XII (1995), apéndice documental. Sobre el puerto de Leça de Matosinhos, vid. POLÓNIA, A.: "O Porto nas navegações ultramarinas quinhentistas. Embarcações e náuticos”, História. Revista da Faculdade de Letras, III série, vol. 1 (2000), pp. 29-52.

91 El oficio de volanteiro estaba vinculado a la producción textil de seda y no a la red de pesca llamada "volanteira". ANTT, TSO, CG, Habilitações, Brás, mç. 1, doc. 9. ANTT, TSO, CG, Habilitações, Francisco, mç. 2, doc. 62. ANTT, TSO, CG, Habilitações, António, mç. 3, doc. 105. ANTT, TSO, CG, Habilitações, André, mç. 3, doc. 58. 
1717, aquel hijo de arrieros alentejanos podía mirar atrás con orgullo lo que había sido su vida ${ }^{92}$.

\section{Las canonjías doctorales: espacios para la élite y la promoción social}

Las canonjías doctorales constituyeron lugares elitistas en el contexto de la estructura institucional de la Iglesia en Portugal. Eran elitistas, en primer lugar, porque todos los cabildos se presentaban como lugares que congregaban a los mejores y más honrados dentro del clero, como ha señalado Díaz Rodríguez. Pero lo eran también por su reducidísimo número, dado que sólo había diez canonjías doctorales de patronato regio provistas por concurso en la Universidad: las de las diócesis antiguas del reino $^{93}$. Las doctorales de las diócesis nuevas, creadas en el XVI, apenas se diferenciaban de las demás prebendas capitulares de sus cabildos. Es cierto que, también en los cabildos antiguos, las doctorales proporcionaban las mismas rentas que las demás canonjías, muy alejadas en algunos casos de las que ofrecían algunas dignidades. No obstante, desde principios del XVII la mayoría de sus poseedores las percibían sin tener que cumplir con ningún tipo de carga u obligación, dado que formaban parte del Santo Oficio y gozaban del privilegio inquisitorial de non residendo.

Estos canónigos constituyeron una élite que se fue definiendo a lo largo de la primera mitad del siglo XVII sustentada en otras tres instituciones: la Universidad, de la que eran profesores, los colegios mayores, que les proporcionaban prestigio y vínculos, y la Inquisición, que les ofrecía la certificación pública de su limpieza de sangre, poder simbólico y el disfrute de un privilegio -el del quinquenio- que les permitía percibir las rentas de sus beneficios sin residir en ellos. En los casos más exitosos, estos cuatro pilares -Universidad, Inquisición, colegio mayor y cabildo- fueron el escalón previo para el ascenso a los altos tribunales de justicia, al Desembargo do Paço y a los obispados.

Desde un punto de vista social, las canonjías doctorales quedaron preferentemente en manos de tres grupos: la fidalguia no titulada $(17,6 \%)$, el patriciado urbano $(23,5 \%)$ y los magistrados $(16,1 \%)$. Los que integraban estos sectores constituían en sus ámbitos respectivos -a veces el nacional y a veces el local- una élite por linaje, rentas o poder. Los pocos canónigos doctorales que alcanzaron un obispado en los siglos XVI y XVII procedían de estos tres grupos sociales y, en la mayoría de los casos, su promoción a la mitra se encuentra vinculada a su carrera inquisitorial previa.

Por otra parte, resulta evidente que estas prebendas no interesaron demasiado a la nobleza titulada, muy reducida en Portugal. A pesar de ello, la aristocracia titulada $-\mathrm{O}$ sus segundones- no dejó de proporcionar algún que otro doctoral, ministro también del Santo Oficio que, sin embargo, no realizó carrera como profesor universitario ni alcanzó luego un obispado ${ }^{94}$.

Cabría preguntarse hasta qué punto fueron utilizadas por grupos sociales medios en proceso de ascenso social. Parte de los doctorales procedía de las mesocracias

92 ANTT, TSO, CG, Habilitações, Pedro, mç. 12, doc. 287. ANTT, TSO, CG, Habilitações, António, mç. 13, doc. 472 .

93 Recordemos que en el cabildo de Coimbra existían dos canonjías doctorales de patronato regio.

94 Apenas Nuno da Silva Teles enseñó, durante un tiempo, en la Universidad, sin llegar a alcanzar nunca una cátedra propia. 
constituidas por poderosos rurales $(10,2 \%)$, escribanos, abogados y otros oficios públicos $(14,7 \%)$ y mercaderes y propietarios de navíos $(5,8 \%)$. En total, casi un tercio de estas canonjías quedaron en manos de gentes que podríamos integrar en la medianía social. El acceso de estas gentes al cabildo constituyó el fin de su carrera eclesiástica, pues ninguno fue promovido después a un obispado. Por el contrario, en algún caso sí tuvieron éxito en sus carreras académicas e incluso llegaron a desempeñar el oficio de desembargador en uno de los altos tribunales de justicia.

A medida que avanzó el siglo XVII, se fue produciendo una ligerísima evolución en el perfil social de los canónigos doctorales. Durante toda la centuria, se mantuvo constante el porcentaje de aquellos que habían nacido en el seno del patriciado urbano y de familias de magistrados. Resulta lógico si tenemos en cuenta los requisitos de formación universitaria necesarios para poder optar a este tipo de prebendas. Por su parte, la mayoría de los miembros de la nobleza titulada y de la fidalguia obtuvieron las doctorales en la segunda mitad del siglo XVI o en la primera del siglo XVII. Por el contrario, prácticamente todos los hijos de hacendados rurales y todos los de mercaderes accedieron a ellas en la segunda mitad del siglo XVII. Esta realidad estaría en consonancia con la evolución de la composición social de las instituciones capitulares castellanas. Así, por ejemplo, a mediados del siglo XVII, el 68,7\% de los miembros del cabildo de Córdoba procederían de la medianía social, si bien conviene tener presente que en ese porcentaje están integrados los magistrados que nosotros hemos contado en el grupo de las élites debido a las características propias de la realidad portuguesa. La misma relevancia de los grupos intermedios en el siglo XVII fue señalada por Antonio Irigoyen para el caso de la catedral de Murcia ${ }^{95}$. En Portugal, la Universidad y la Inquisición fueron utilizadas por grupos que, enriquecidos por sus actividades agrarias, especulativas y comerciales, decidieron destinar a uno o varios de sus miembros a estas carreras que les permitieron, en algunos casos, el ascenso a los altos tribunales de justicia. Estos grupos abandonaron tan pronto como pudieron las actividades mercantiles, intentaron integrarse en las élites municipales, buscaron signos de honra y distinción y destinaron a otros miembros al servicio en la magistratura regia.

Por lo tanto, las canonjías doctorales constituyeron un elemento utilizado en procesos de promoción y consolidación social, pero lo fueron como un apéndice de otros más relevantes como el servicio en la Inquisición, la docencia en la Universidad de Coimbra y el desempeño de cargos en la Relação do Porto, la Casa da Suplicação, el Desembargo do Paço o la Mesa da Consciência e Ordens. Precisamente por ello, por estar cada vez más vinculados al Tribunal del Santo Oficio y a la Universidad y, en menor medida, a los altos tribunales de justicia y los Consejos, los canónigos doctorales nunca perdieron su carácter elitista y siempre se mantuvieron como un elemento diferente, foráneo, cada vez más separado de los cabildos a los que nominalmente pertenecían y cuyas rentas disfrutaban.

95 Díaz Rodríguez, "Una mesocracia eclesiástica. El peso de la medianía social en los cabildos andaluces en el siglo XVII", en este mismo número de los Cuadernos de Historia Moderna. Irigoyen, op. cit. (nota 27), pp. 201-2018. 


\section{Bibliografía}

Bloch, M.: Apología para la historia o el oficio del historiador, México, FCE, 2001.

Bethencourt, F.: La Inquisición en la época moderna. España, Portugal, Italia, siglos XVXIX, Madrid, Akal, 1997.

Brito, P. de: Patriciado urbano quinhentista: as famílias dominantes do Porto (1500-1580), Porto, Câmara Municipal do Porto, 1997.

Camarinhas, N.: Juizes e administração da justiça no Antigo Regime: Portugal e o império colonial, séculos XVII e XVIII, Lisboa, FCG-FCT, 2010.

Cunha, M. Soares da: A Casa de Bragança. 1560-1640. Práticas senhoriais e redes clientelares, Lisboa, Editorial Estampa, 2000.

Cunha, M. Soares da y Fonseca, T. (eds.): Os Municípios no Portugal Moderno. Dos forais manuelinos às reformas liberais, Lisboa, Edições Colibri - CIDEHUS/UE, 2005.

Cunha, M. Soares da y Monteiro, N.: "Jerarquía nobiliaria y Corte en Portugal (siglo XV1832)", en Chacón Jiménez, F. y Monteiro, N. (eds.): Poder y movilidad social. Cortesanos, religiosos y oligarcas en la Península Ibérica (siglos XV-XIX), Madrid, CSIC - Universidad de Murcia, 2006, pp. 181-212.

Dedieu, J.-P.: "Limpieza, poder y riqueza. Requisitos para ser ministro de la Inquisición. Tribunal de Toledo, siglos XVI-XVII", Cuadernos de Historia Moderna, 14 (1993), pp. 29-44.

Dedieu, J.-P.: "Hábitos o condecoraciones ¿Unos instrumentos para la vertebración de la clase política?", en López-Salazar, A. I.; Figueirôa-Rêgo, J., y Olival, F. (coords.): Honra e sociedade no mundo ibérico e ultramarino. Inquisição e Ordens Militares, Lisboa, Caleidoscópio, 2013, pp. 295-313.

Dedieu, J.-P.: "La importancia del actor. Reflexiones sobre el porvenir de la Historia Social", Estudis (en prensa).

Díaz Rodriguez, A. J.: El clero catedralicio en la España Moderna: los miembros del Cabildo de la Catedral de Córdoba (1475-1808), Murcia, Universidad de Murcia, 2012.

Díaz Rodríguez, "Una mesocracia eclesiástica. El peso de la medianía social en los cabildos andaluces en el siglo XVII", Cuadernos de Historia Moderna, 46.2 (2021), pp. 667-695.

Falcão, L. de Figueiredo: Livro em que se contém toda a fazenda e real património dos reinos de Portugal, Índia e Ilhas adjacentes, Lisboa, Imprensa Nacional, 1859.

Hespanha, A. M.: As vésperas do Leviathan. Instituçoes e poder politico. Portugal - sec. XVII, Rio de Mouro, ed. do autor, 1986, 2 vols.

Hespanha, A. M.: As vésperas do Leviathan. Instituições e poder político. Portugal-século XVII, Coimbra, Almeida, 1994.

Irigoyen López, A.: Entre el cielo y la tierra, entre la familia y la institución. El cabildo de la catedral de Murcia en el siglo XVIII, Murcia, Universidad de Murcia, 2001.

Labrador Arroyo, F.: La Casa Real portuguesa de Felipe II y Felipe III: la articulación del reino a través de la integración de las élites de poder (1580-1621), Madrid, tesis doctoral defendida en la Universidad Autónoma de Madrid, 2006.

Labrousse, E.: "Conclusion”, en Ordres et classes, Paris-La Haye, EPHE - Mouton, 1973, pp. 267-269.

López-Salazar, A. I.: "Una oligarquía eclesiástica en Portugal durante el Antiguo Régimen: catedráticos, canónigos e inquisidores", Libros de la Corte, monográfico 6, año 9 (2017), pp. 164-184.

Magalhães, J. Romero: O Algarve Económico, 1600-1773, Lisboa, Editorial Estampa, 1993. Magalhães, J. Romero: "Os Concelhos", en Idem (coord.): No Alvorecer da Modernidade (1480-1620), Lisboa, Editorial Estampa, 1993, pp. 175-185. 
Magalhães, J. Romero: “A sociedade”, en Idem (coord.): No Alvorecer da Modernidade (1480-1620), Lisboa, Editorial Estampa, 1993, pp. 469-509.

Magalhães, J. Romero: “As estruturas sociais de enquadramento da Economia Portuguesa de Antigo Regime: os concelhos", Notas Económicas, 4 (1994), pp. 30-47.

Monteiro, N.: "Elites locais e mobilidade social em Portugal nos finais do Antigo Regime", en Idem: Elites e Poder. Entre o Antigo Regime e o Liberalismo, Lisboa, ICS, 2007, pp. 37-81.

Monteiro, N.: "Poderes e circulação das elites em Portugal: 1640-1820", en Idem: Elites e Poder. Entre o Antigo Regime e o Liberalismo, Lisboa, ICS, 2007, pp. 105-138.

Monteiro, N.: "Nobleza y élites en el Portugal moderno en el contexto de la Península Ibérica (siglos XVII y XVIII)", en Soria Mesa, E. y otros (eds.): Las élites en la época moderna: la monarquía española, Córdoba, Universidad de Córdoba, 2009, vol. 1, pp. 143-155.

Olival, F.: As Ordens Militares e O Estado Moderno. Honra, mercê e venalidade em Portugal (1641-1789), Lisboa, Estar, 2001.

Olival, F. y Monteiro, N.: "Mobilidade social nas carreiras eclesiásticas em Portugal (15001820)", Análise Social, vol. 37, n. 165 (2003), pp. 1213-1239.

Oliveira, A.: A vida econômica e social de Coimbra de 1537 a 1640, Coimbra, Palimage, 2016 [1971-1972].

Paiva, J. P.: Os bispos de Portugal e do Império: 1495-1777, Coimbra, Imprensa da Universidade de Coimbra, 2006.

Paiva, J. P.: "D. Fr. Luís da Silva e a gestão dos bens de uma mitra. O caso da diocese de Lamego (1677-85)", en Ramos, Luís A. Oliveira, Ribeiro, J. Martins, e Polónia, A. (coords.): Estudos de homenagem a João Francisco Marques, Porto, Faculdade de Letras da Universidade do Porto, 2001, vol. II, pp. 245-255.

Pardal, R.: As elites de Évora ao tempo da dominação filipina. Estratégias de controlo do poder local (1580-1640), Edições Colibri - CIDEHUS/UE, 2007.

Polónia, A.: "Mestres e pilotos das carreiras ultramarinas (1596-1648)", Revista da Faculdade de Letras - História, II série, vol. XII (1995), pp. 271-353.

Polónia, A.: "O Porto nas navegações ultramarinas quinhentistas. Embarcações e náuticos", História. Revista da Faculdade de Letras, III série, vol. 1 (2000), pp. 29-52.

Rodrigues, M. A. (dir.): Memoria Professorum Universitatis Conimbrigensis, Coimbra, Arquivo da Universidade de Coimbra, 2003, vol. 1.

Rodrigues, T.: “As vicissitudes do povoamento nos séculos XVI e XVII”, en Eadem (coord.): História da população portuguesa. Das longas permanências à conquista da modernidade, CEPESE e Edições Afrontamento, 2009, pp. 159-246.

Serrão, J. V.: “O quadro humano", en Hespanha, A. M. (coord.): O Antigo Regime (16201807), Lisboa, Editorial Estampa, 1993, pp. 49-69.

Serrão, J. V.: "População e rede urbana nos séculos XVI-XVIII", en Oliveira, C. (dir.): História dos municípios e do poder local (dos finais da Idade Média à União Europeia), Lisboa, Círculo de Leitores, 1996, pp. 63-77.

Serrão, J. V.: "Lavradores", en Madureira, N. L. (coord.): História do trabalho e das ocupações, vol. III, Oeiras, Celta Editora, 2002, pp. 64-76.

Silva, A. M. Dias da: "Processos para Dignidades e beneficiados da Sé de Coimbra: origem geográfica", en Casa Nobre: Um Património para o Futuro, Actas $-3^{\circ}$ Congresso Internacional, Arcos de Valdevez, Município de Arcos de Valdevez, 2013, pp. 370-389.

Silva, F. Ribeiro da: O Porto e o seu termo (1580-1640): os homens, as instituições e o poder, Porto, Câmara Municipal do Porto, 1988.

Silva, H. R.: O cabido da Sé de Coimbra. Os homens e a instituição. 1620-1670, Lisboa, ICS, 2010. 
Silva, H. R.: O clero catedralício portugués e os equilibrios sociais do poder (1564-1670), Lisboa, UCP-CEHR, 2013.

Silva, H. R.: "O cabido", en Paiva, J. P. (coord.): História da Diocese de Viseu, Viseu-Coimbra, Diocese de Viseu-Imprensa da Universidade de Coimbra, 2016, vol. 2, pp. 225-262.

Soria Mesa, E.: "Los estatutos municipales de limpieza de sangre en la Castilla moderna. Una revisión crítica", Mediterranea - ricerche storiche, 27 (2013), pp. 9-36.

Soria Mesa, E.: La realidad tras el espejo: ascenso social y limpieza de sangre en la España de Felipe II, Valladolid, Universidad de Valladolid, 2016.

Stumpf, R.: "Os provimentos de ofícios: a questão da propriedade no Antigo Regime português", Topoi, vol. 15, n. 29 (2014), pp. 612-634.

Subtil, J. (coord.): Dicionário dos Desembargadores: 1640-1834, Lisboa, EDIUAL, 2010. 